\title{
Macroporosity of a Typic Argiudoll with different cropping intensity under no-tillage
}

\section{AUTHORS \\ Behrends Kraemer F.1,@ \\ filipebk@agro.uba.ar}

Morrás H.J. M. ${ }^{2}$

@ Corresponding Author

${ }^{1}$ Cátedra de Manejo y

Conservación de Suelos

Facultad de Agronomía,

Universidad de Buenos

Aires. CONICET

(Consejo Nacional

de Investigaciones

Científicas y Técnicas).

Argentina.

2 Instituto de Suelos,

INTA (Instituto

Nacional de Tecnología

Agropecuária. Argentina.

\begin{abstract}
Macroporosidad de un Argiudol Típico bajo siembra directa con diferentes intensidades de cultivo Macroporosidade de um Argiudol Típico sujeito a plantio direto com diferentes intensidades de cultivo
\end{abstract}

Received: 09.05.2017 | Revised: 27.02.2018 | Accepted: 04.06.2018

\section{ABSTRACT}

Soil macropores are dominant pathways of water flow and their impact on hydraulic properties is directly related to their geometrical and topological characteristics. A number of field and micromorphological analysis have shown that agriculture management under no-tillage promotes the development of a microstructure characterized by platy aggregates and horizontal planes in the topsoil, together with a densification at a subjacent layer, thus raising questions about physical properties and water dynamics under this system of cultivation. Moreover, scarce information is available about the evolution of pore architecture and physical parameters in soils under no-till with different cropping intensity. The objective of this work was to evaluate soil porosity in a silty loam A horizon of a Typic Argiudoll (Monte Buey series) of northern Pampa Region (Argentina) under two no-tilled contrasting managements: Good Agricultural Practices (GAP) -highly intensified cropping sequence including corn and wheat in addition to soybean-, Poor Agricultural Practices (PAP) -simplified crop sequence, with predominance of soybean- and a Natural Environment (NE) as reference. Topsoil porosity was assessed by micromorphology, micromorphometry and water retention curves approach, and the values obtained were related to some physical and chemical variables. Results of the morphological analysis revealed important differences between both agricultural treatments. In the surface layer in GAP, platy aggregates are thick and result from the cohesion of rounded microaggregates of biological origin; in PAP they are thin and dense, resulting mostly from compaction of individual soil particles and small microaggregates. A soil densification is evident in both agricultural treatments at $5-10 \mathrm{~cm}$ depth, although the morphology and size of aggregates and pores also differ between them. Micromorphometric analyses have shown differences in total macroporosity as well as in the size, morphology and orientation of macropores between both treatments. Macroporosity values obtained by digital methods were coincidently reflected by the pressure plate method. Porosity variables measured by digital analysis, in particular elongated pores and pore orientation, appear more sensitive than other soil properties (total carbon, aggregate stability, bulk density) in discriminating treatments. Although no-till cultivation led to the formation of platy microstructures and a decrease of soil porosity compared to $\mathrm{NE}$, both agricultural treatments presented optimal values of Ks and water movement was not impaired. As expected, all morphological and analytical soil variables were better in the NE treatment. In addition, it was interesting to verify that the values of several parameters were close or similar between GAP and NE. Even when more intensified crop sequence (GAP) increases machinery traffic, morphological, physical and chemical soil properties were here improved compared to PAP. In this case, the higher proportion of different graminea into the agricultural cycle, besides its effect on the development of root biopores, seems to promote a higher fauna activity which effectively counteracts the vertical mechanical compression produced by traffic. These results suggest 
that, in addition to the known benefits of non-tillage on soil conservation, the improvement of various soil properties could be achieved by integrating this method of cultivation with suitable agricultural managements.

\section{RESUMEN}

Los macroporos del suelo son vias preferenciales del flujo de agua y su impacto sobre las propiedades hidráulicas está directamente relacionado con sus características geométricas y topológicas. Numerosos análisis micromorfológicos $y$ de campo han demostrado que manejos agricolas bajo siembra directa (SD) promueven el desarrollo de una microestructura caracterizada por agregados laminares y poros planares en el estrato superior del suelo, asociado a una densificación en el estrato subyacente, planteando, de esta forma, incertidumbres sobre la dinámica de las propiedades físicas y la dinámica del agua bajo este sistema de cultivo. Además, es escasa la información sobre la evolución de la arquitectura poral asociada a parámetros físicos en suelos bajo SD con diferentes manejos agrícolas. El objetivo de este trabajo fue evaluar la porosidad del suelo en el horizonte A franco limoso de un Argiudol Típico (serie Monte Buey) de la región norte de la Pampa (Argentina) bajo dos intensidades de cultivo contrastantes bajo SD: Buenas Prácticas Agricolas (BPA) - secuencia altamente intensificada incluyendo los cultivos de maiz y trigo además de la soja-, Malas Prácticas Agrícolas (MPA) -secuencia de cultivos simplificada con predominio de soja- y un Ambiente Natural (AN) como referencia. La porosidad del estrato superficial fue evaluada mediante análisis micromorfológicos, micromorfométricos y a partir de la determinación de curvas de retención hídrica. Además se evaluaron diversas variables hidrofísicas. Los resultados del análisis morfológico revelaron diferencias importantes entre ambos tratamientos agricolas. En el estrato superior de BPA, los agregados laminares son de gran tamaño y resultan de la cohesión de microagregados redondeados de origen biológico; en MPA son de menor tamaño, densos, resultantes principalmente de la compactación de partículas individuales y pequeños microagregados. En el estrato 5-10 cm, la densificación del suelo es evidente en ambos tratamientos agricolas, si bien la morfología y el tamaño de los agregados y poros difieren entre ellos. Los análisis micromorfométricos mostraron diferencias en la macroporosidad total, asi como en el tamaño, morfología y orientación de los macroporos entre ambos tratamientos agrícolas. Los valores de macroporosidad obtenidos por métodos digitales fueron coincidentes con el método de curvas de retención hidrica. Además, las variables de porosidad determinada por análisis digitales, en particular los poros alargados y la orientación de dichos poros, parecen más sensibles que otras propiedades del suelo (carbono total, estabilidad del agregado, densidad aparente) para discriminar los tratamientos. Aunque la SD dio lugar a la formación de microestructuras laminares y una disminución de la porosidad del suelo en comparación con el AN, ambos tratamientos agricolas presentaron valores óptimos de Ks, no afectando el movimiento del agua. Como era de esperar, todas las variables morfológicas y analiticas del suelo fueron mejores en el Ambiente Natural. Además, fue interesante verificar que los valores de varios parámetros fueran cercanos o similares entre BPA y AN. Incluso cuando la secuencia de cultivo más intensificada (BPA) aumenta el tráfico de maquinaria, varias propiedades morfológicas, físicas y químicas del suelo se ven favorecidas. En este caso, la mayor proporción de gramíneas en el ciclo agricola, además de su efecto sobre el desarrollo de bioporos radiculares, parece promover una mayor actividad de la fauna, la cual contrarresta eficazmente la compresión mecánica vertical producida por el tráfico. Estos resultados sugieren que, además de los beneficios conocidos de la SD en la conservación del suelo, es posible la mejora de varias propiedades edáficas asociando este sistema de cultivo con manejos agricolas adecuados.

\section{RESUMO}

Os macroporos do solo são vias preferenciais para o escoamento da água e o seu impacto nas propriedades hidráulicas está diretamente relacionado com as suas características geométricas e topológicas. Uma série de análises micromorfológicas e de campo mostraram que a gestão agricola em plantio direto (PD) promove o desenvolvimento de uma microestrutura caracterizada por agregados laminares e poros planares na camada superior do solo associada a uma densificação na camada subjacente, levantando assim questões sobre as propriedades físicas do solo e a dinâmica da água sob este sistema de cultivo. Além disso, é escassa a informação disponivel sobre a evolução da arquitetura dos poros e dos parâmetros físicos em solos sob PD com diferentes intensidades de cultivo. O objetivo deste trabalho foi o de avaliar a porosidade do solo no horizonte A franco siltoso de um Argiudol Típico (série Monte Buey) da região norte da Pampa Argentina submetido a intensidades de cultivo contrastantes em PD: Boas Práticas Agrícolas (BPA) - sequência altamente intensificada incluindo cultura de milho e trigo além da soja-, Más Práticas Agricolas (MPA) - sequência de culturas simplificada com predominio de soja e um ambiente natural (AN) 
como referência. A porosidade da camada superficial do solo foi avaliada através de análises micromorfológicas, micromorfométricas e pela determinação de curvas de retenção de água. Os dados obtidos foram correlacionados com algumas variáveis físicas e químicas do solo. Os resultados da análise morfológica indicaram diferenças importantes entre os dois tratamentos. $\mathrm{Na}$ camada superficial de BPA, os agregados laminares são espessos a resultam da coesão de microagregados arredondados de origem biológica; em MPA aqueles agregados são finos e densos, e são principalmente resultantes da compactação de partículas individuais do solo e pequenos microagregados. Na camada de 5-10 cm é evidente a densificação do solo em ambos os tratamentos agricolas, embora a morfologia e a dimensão dos agregados e dos poros sejam diferentes. As análises micromorfométricas mostram diferenças na macroporosidade total assim como no tamanho, morfologia e orientação dos macroporos entre ambos os tratamentos. Os valores da macroporosidade obtidos por métodos digitais eram coincidentes com os obtidos pelas curvas de retenção hídrica. As variáveis da porosidade determinada por análise digital, em particular dos poros alongados e da sua orientação parecem mais sensiveis do que outras propriedades do solo (carbono total, estabilidade dos agregados, densidade aparente) para discriminar os tratamentos. Embora a SD desse lugar à formação de microestruturas laminares e a uma diminuição da porosidade do solo quando comparada com AN, ambos os tratamentos agrícolas apresentaram valores ótimos de Ks que não afetaram o movimento da água. Tal como esperado, todas as variáveis morfológicas $e$ analiticas do solo foram melhores no Ambiente Natural. Além disso, foi interessante verificar que os valores dos vários parâmetros eram próximos ou semelhantes entre BPA e AN. Mesmo quando a sequência de cultivo mais intensa (BPA) aumentou o tráfego de maquinaria, várias propriedades morfológicas, físicas e químicas do solo foram melhoradas comparativamente a MPA. A maior proporção de diferentes gramíneas no ciclo agrícola, além do seu efeito no desenvolvimento de bioporos radiculares, parece promover uma elevada atividade da fauna, a qual contraria eficazmente a compressão mecânica vertical produzida pelo tráfego. Estes resultados sugerem que, para além dos benefícios conhecidos da SD na conservação do solo, poderá obter-se uma melhoria de várias propriedades do solo associando este sistema de cultivo com práticas de gestão agrícola adequadas.

\section{Introduction}

Soil porosity is a key feature determining soil quality. Particularly, macropores are dominant pathways of water flow and several studies highlight the fact that their impact on hydraulic properties is directly related to their geometrical and topological characteristics (Vandenbygaard et al. 1999; Pagliai et al. 2004; Rasa et al. 2012). Elongated pores are of particular agronomic interest since various studies indicate that the larger categories of this pore type and their number correlate positively with the movement of air and water in the soil (Pagliai et al. 2003; Castiglioni et al. 2007), while in turn they are the most affected by agricultural management (Pachespky et al. 1996; Fernández et al. 2012; Rasa et al. 2012). Thus, changes in pore number, pore size distribution and pore shape pattern as a consequence of cultivation have been used to assess changes in hydraulic conductivity (Kutílek 2004; Morrás et al. 2008; Pires et al. 2017), effects of machinery compaction (Pagliai et al. 1984; Vandenbygaard et al. 1999; Álvarez et al. 2014), influence of cattle grazing (Fernández et al. 2012; Rasa et al. 2012) and earthworm activity (Vandenbygaart et al. 2000).

Changes in soil use and agricultural practices modify soil structure and porosity, frequently leading to a decline in soil quality (Reynolds et al. 2002; Bonel et al. 2005; Álvarez et al. 2014). Conservation agricultural practices, such as no-tillage (NT) are considered 
more sustainable than conventional intensive practices, because they do not modify the natural soil properties as abruptly and deeply, and compared to soil ploughing-sometimes improve some of them (Derpsch 2002; Kirkegaard and Hunt 2010). It has been shown that NT improves structural stability (Álvarez and Steinbach 2009; Álvarez et al. 2012), increases water storage, and reduces soil loss (Derpsch et al. 2010). However in Argentina, the widespread use of NT is scarcely coupled with crop rotation (Austin et al. 2006; Novelli et al. 2011), and a high frequency of soybean in the crop sequence is often reported (Novelli et al. 2011; Viglizzo et al. 2011) with associated negative consequences for soil carbon content, aggregate stability and water infiltration as well as increases in soil erosion (Novelli et al. 2011, 2013; Agostini et al. 2013; Maggi et al. 2016; Sasal et al. 2006). In this system a permanent organic soil cover is required to offset some negative aspects of no-till farming on soil architecture (Vázquez et al. 1989; Bonel et al. 2005), but the scarce residue with low $\mathrm{C} / \mathrm{N}$ ratio of soybean crops does not achieve this requirement (Studdert and Echeverría 2000).

In fact, contrasting results have been obtained concerning the effect of NT on soil porosity and compaction. Studies conducted by some authors have highlighted that soil density and penetration resistance is greater under NT than under conventional tillage (Mahboubi et al. 1993; Pagliai and De Nobili 1993; Chagas et al. 1994; Tebrügge and Düring 1999), often imparing water movement through soils. On the contrary, Thomas et al. (1996) and Mallory et al. (2011) showed lower bulk density values under NT.

In addition, water entry restrictions in silty soils under NT have been reported as consequence of the presence of platy structures (Pagliai et al. 1983; Ball and Robertson 1994). These structures have also been described in field evaluations of soils under NT in the Pampas region of Argentina (Sasal et al. 2006; Álvarez et al. 2014; Lozano 2015; Kraemer et al. 2017) and through micromorphological analyses (Morrás et al. 2004, 2008, 2012; Bonel et al. 2005; Álvarez et al. 2014). Several mechanisms have been proposed to explain the common appearance of platy structures in non freeze-thaw soils under NT: previous compaction of subjacent soil layers, soybean monoculture or high soybean frequency on the crop sequence (Sasal et al. 2017a) and machinery traffic (Morrás et al. 2004, 2012; Álvarez et al. 2014).

Despite the higher bulk density and lower total porosity under NT, in many cases water infiltration is equal to or higher than systems under conventional tillage (Bauder et al. 1981). This has been attributed to a higher aggregate stability leading to more stable and interconnected macropores related to a higher biological activity (Zacagnini and Calamari 2001). Also, some authors remark that platy structures are not homogenous, varying their continuity, thickness and conformation and must not be seen as a determinant of soil quality, as production yield may not be strongly affected by this structure (Cavalieri et al. 2009; Kraemer et al. 2017).

Many other factors may explain these divergent results obtained under NT, such as differences on soil type, climatic conditions, and crop sequences intensification $(\mathrm{Cl})$. On this last point, and opposite to crop simplification due to soybean monoculture, in the Pampas region (the main crop area in Argentina), many farmers have intensified the crop sequence due to the inclusion of two crops per year, such as wheat/ soybean or wheat/late corn (Caviglia and Andrade 2010) with different results in terms of soil quality. Higher $\mathrm{Cl}$ have shown increases in carbon storage and aggregate stability and a reduction in soil erosion (Novelli et al. 2011, 2013; Agostini et al. 2013;) while in contrast Wilson et al. (2010) and Duval et al. (2015) found lower soil porosity and higher bulk density with increasing $\mathrm{Cl}$. Due to these contrasting effects, the consequences of $\mathrm{Cl}$ under NT on edaphic properties are still uncertain. Moreover, scarce information is available about the evolution of pore architecture and physical parameters under NT with crop intensification.

The objective of this work was to evaluate soil macroporosity in the A horizon of a silty loam Typic Argiudoll (Monte Buey series) of the northern Pampa Region (Argentina) under two NT treatments contrasting in cropping intensity and a Natural Environment (NE) as reference. To obtain quali-quantitative integrative data on pore sizes and shapes, a micromorphometric 
study was carried on soil thin sections by means of image analyses. Macroporosity was also determined by the water retention curve approach for comparison purposes, and porosity parameters were related to some chemical and physical variables.

\section{Materials and Methods}

\subsection{Study site and soil treatments}

Soil site and managements were selected by scientists and farmers of the BIOSPAS consortium. This interdisciplinary project has the long term goal of defining ecological indicators of sustainability under no-till farming (Wall 2011). The study site is located in Monte Buey (Córdoba province, Argentina; $32^{\circ} 58^{\prime} 14^{\prime \prime} \mathrm{S}$; $62^{\circ} 27^{\prime} 61^{\prime \prime} \mathrm{W}$ ) in a flat area in the limit between the Piedmont Pampa and the Rolling Pampa. The soil under study is a silty loam Typic Argiudoll (Soil Survey Staff 1999), Monte Buey series, with a moderately developed illuvial Bt horizon.

Two agricultural practices were evaluated under NT: Good Agricultural Practices (GAP) and Poor Agricultural Practices (PAP), both following the criteria of the AAPRESID program for Certification in Good Agricultural Practices (http://www. aapresid.org.ar/ac/buenas-practicas-agricolas/) and the Good Agricultural Practice guidelines developed by FAO (www.fao.org/prods/GAP/index en.htm).

GAP is characterized by intensive crop sequences (more crops during the year mainly due to the inclusion of winter crops), a low soybean crops/ total crops ratio (0.28), high stubble cover, good nutrient replacement and optimal use of agrochemicals. The index of intensification proposed by Caviglia and Andrade (2010) and Sasal et al. (2010) (ISI: intensification of the crop sequence index) reaches here a value of 0.64 . This plot has been cultivated 28 years under NT.

PAP is distinguished by a lower crop intensification (ISI: 0.49), high soybean crops/total crops ratio: 0.75 , low nutrient replacement, high use of agrochemicals and low yields. The plot has been 10 years under NT. It must be noted that only GAP could be considered to follow all of the NT system assumptions (diverse crop rotation, optimal use of agrochemical, pest control, etc.) according to Aapresid criteria and Derpsch et al. (2014), whereas PAP only share the nonsoil remotion characteristics of this method of cultivation. In addition, results were compared with a reference system designated as Natural Environment (NE), a natural grassland that had not been tilled for at least 30 years, located less than $5 \mathrm{~km}$ from the sampling area of GAP and PAP treatments.

Granulometry data of the A soil horizon for each treatment were: NE: $22.6 \%$ clay, $60.8 \%$ silt; GAP: $24.6 \%$ clay, $58.1 \%$ silt; PAP: $20.2 \%$ clay, $62.3 \%$ silt. All treatments presented mild acidity (5.9-6.3). Clay fraction is composed mainly by illites followed by interestratified illite/smectite, a low proportion of kaolinite and accessory minerals such as quartz and feldspars (Kraemer et al. 2014). Soil and climate characteristics are described in more detail elsewhere (Figuerola et al. 2012; Rosa et al. 2014; Kraemer et al. 2017)

\subsection{Micromorphology and micromorphometric analyses}

Undisturbed soil samples were taken in Kubiena boxes at $0-5 \mathrm{~cm}$ and $5-10 \mathrm{~cm}$ for agricultural managements (GAP and PAP) and only from topsoil for the reference plot (NE). Previous works in the same locations have shown that the first $15 \mathrm{~cm}$ depth in NE have a rather homogeneous macrostructure and behaves as an isotropic horizon (Kraemer et al. 2017). Soil samples were air dried and impregnated under vacuum with polyester resin. Polymerization time was approximately 8 weeks at room temperature including final curing for 1 day at $40^{\circ} \mathrm{C}$ in the oven. Oriented soil thin sections (thickness: $30 \mu \mathrm{m}$ ) were analyzed by optical microscopy in transmitted and cross-polarized light (Leica Wild MZ8). Micromorphological descriptions were made according to the criteria and terminology proposed by Stoops (2003) and its updating in Loaiza et al. (2015). 
Digital images were obtained from each sample with a Cannon Powershot S3IS 6MP, coupled with Image Capturec software and soil porosity parameters were assessed by image analysis with the JMicro-Vision v1.2 program (Roduit 2008).

Following the procedure described by Pastorelli et al. (2013) a portion of each thin section was selected, avoiding edges where disruption could have occurred. Details on digitalization and segmentation procedures can be found in Kraemer et al. (2018). After digitalization, subsets of the thin section were selected (n: 4, $2.25 \mathrm{~cm}^{2}$ each) in order to avoid gray tone differences that could lower segmentation accuracy. Due to the high proportion of white minerals (e.g. quartz, feldspar) in the samples, the procedure proposed by Moretti et al. (2012) was followed to remove them from the images to obtain correct porosity values. Taking into account area selection and false pore deletion, a segmentation threshold ( 150) did not vary more than two units. This threshold was supervised in each sample by visual inspection and most of those thresholds were located near the inflection point of the image spectral curve.

This study focused on the analysis of macropores, considered to be those greater than $50 \mu \mathrm{m}$ (Pagliai 1987; Pagliai and Kutilek 2008), as they are responsible for the movement of air, water and root growth (Greenland 1977; Vandenbygaard et al. 1999). The areal porosity (AP) was obtained by dividing the total area of the selected crosssection of the pore space by the total sample area and it was expressed as a percentage (Pires et al. 2008). Thus, porosity of the image is here termed digital macroporosity (DM > $50 \mu \mathrm{m}$ ). The size distribution of pores was classified according to their equivalent pore diameter into seven size classes $(50-100,100-200$, 200-400, 400-800, 800-1000 and > $1000 \mu \mathrm{m}$. The $>1000 \mu \mathrm{m}$ class $(\mathrm{DM}>1000 \mu \mathrm{m})$ was particularly considered as this size was suggested as a large macropore variable (Watson and Luxmoore 1986; Imhoff et al. 2010). Also, transmission pores (DM 50-500 $\mu \mathrm{m}$ ) related to water provision to vegetation, were additionally quantified (Greenland 1977).

Pore shape was assessed using a shape factor [Area/Perimeter ${ }^{2}$ ] proposed by Bouma et al.
(1977), where a factor $<0.015$ correspond to elongated pores, a factor between 0.015-0.04 is attributed to irregular pores and a factor $>0.04$ to rounded pores. Pores classified as elongated were studied in more detail. Number of elongated pores for each size classes was measured and two categories of elongated pores were established according to their orientation: vertical and oblique pores $\left(30^{\circ}-150^{\circ}\right)$ and subhorizontal pores $\left(0-30 \% 150-180^{\circ}\right)$.

\subsection{Physical and chemical characteristics}

Samples for bulk density (BD), total porosity, macroporosity $>50 \mu \mathrm{m}\left(\mathrm{P}_{\mathrm{Mac}}>50 \mu \mathrm{m}\right)$, macroporosity $>1000 \mu \mathrm{m}\left(\mathrm{P}_{\mathrm{Mac}}>1000 \mu \mathrm{m}\right)$ and for total organic carbon (TOC) were obtained at three soil depths $(0-5,5-10$ and $10-20 \mathrm{~cm})$ adjacent to the undisturbed soils samples used for microscopic analyses. BD values (core method, Blake and Hartge 1986) were extracted from Duval et al. (2013). These results were obtained in the same sampling sites and moment of the others determinations described here. Porosity variables were determined by means of the water retention curve approach (depth: $\mathrm{n}=9$, cores $100 \mathrm{~cm}^{3}$ ) using pressure plates (Richards 1948). Data were fitted to the van Genuchten (1980) water retention model with Mualem restriction $m=1-1 / n$ (Mualem 1986). Porosity values were obtained with the fitted water retention curves considering the Or and Wraith (2000) equation. Total organic carbon was measured by the dry combustion method using a LECO (LECO, St. Joseph, MI, USA).

Aggregate stability (AS) was determined according to Le Bissonnais (1996). Data were obtained from Rosa et al. (2014). In this study only the mean of the three tests proposed was used $\left(M W D_{\text {mean }}\right)$. To determine this variable, undisturbed soil cores $\left(1500 \mathrm{~cm}^{3}\right)$ were taken from the topsoil $(0$ to $15 \mathrm{~cm})$ (12 samples for each treatment). Finally, saturated hydraulic conductivity (Ks) was measured in undisturbed soil samples ( 9 cores per treatment, $135 \mathrm{~cm}^{3}$ ) collected at $0-5 \mathrm{~cm}$ by using the falling-head technique (Klute and Dirsken 1986). Reynolds et al. (2008) and Castellini et al. (2013) consider optimal values of $\mathrm{Ks}$, those ranging between $43.2-432 \mathrm{~cm} \mathrm{~d}^{-1}$. 


\subsection{Statistical analyses}

To determine the significance of treatments on porosity variables (both methods) and physical and chemical soil variables, ANOVA models coupled with LSD (Fisher) was applied with the statistical package InfoStat version 2012 (Di Rienzo et al. 2012). All variables except for $P_{\text {Mac }}$ $(>1000 \mu \mathrm{m}$ ) attained normality (Shapiro Wilkis, $\mathrm{P}<0.05)$. This variable was $\log _{10}$ transformed and presented in their original units in Table 4. Linear regression was performed between $\mathrm{DM}>50 \mu \mathrm{m}$ and total porosity and $\mathrm{P}_{\mathrm{Mac}}>50 \mu \mathrm{m}$ (Snedecor and Cochran 1980). Associations between selected physical and chemical soil variables (TOC, BD, $P_{\text {Mac }}>1000 \mu \mathrm{m}$, $\mathrm{AS}$ and $\mathrm{Ks}$ ) and image analyses variables (DM > $50 \mu \mathrm{m}, \mathrm{DM}>1000 \mu \mathrm{m}$ elongated and rounded pores, transmission pores (DM 50-500 $\mu \mathrm{m}$ ), and elongated pore orientation: $>400 \mu \mathrm{m}$ vertical+oblique $(\mathrm{O} . \mathrm{V})$ or horizontal $(\mathrm{H})$ and $<400 \mu \mathrm{m}$ vertical+oblique or horizontal) were assessed by principal component analysis (PCA) performed on the correlation matrix (Balzarini et al. 2008).

\section{Results}

\subsection{Micromorphological description}

Representative microstructural features of the three different soil treatments at two soil depths are shown in Figure 1, and some morphological details are presented at higher magnification in Figure 2.

In all the treatments evaluated in this silty loam Argiudoll, the groundmass of the A horizon have a c/f $2 \mu \mathrm{m}$ ratio about 80/20, the c/f related distribution is single spaced porphyric, and the b-fabric is undifferentiated. The coarse fraction is composed mainly of quartz, feldspars and micas, a low proportion of volcanic glass, and some phytolites. It has a random basic distribution with grains sizes around $50 \mu \mathrm{m}$. A difference is observed in the colour of the groundmass: it is brown in the GAP and PAP treatments, while it is dark-brown in the NE treatment reflecting its higher humus content. Plant residues are also more abundant in this treatment.

Concerning the microstructure, in the NE treatment the dominant aggregates are subangular blocks (Figures 1a, b, c) and some wavy irregular plates (Figure $1 \mathrm{~b}$ ), all of which are highly porous. Abundant excrements fill channels (Figures 1a and 2a) or they form irregular groups in the groudmass (Figures 1b, c). In some areas, small crumbs and granules clearly related to a coalescence of excrements are frequent. Most of the excrements are small, with a mean size of about $400 \mu \mathrm{m}$ (Figure 2a). The dominant voids are subhorizontal planes and compound packing voids between aggregates, while in the interior of blocks and plates there are small vughs, also frequently resulting from the coalescence and welding of excrements. Thus, the microstructure of the A horizon in NE varies over short distances between subangular blocky and crumb types.

In GAP and PAP treatments the microstructure differs noticeably between both sampling depths. In GAP at 0-5 cm depth, the structure is composed by rounded dense aggregates (granules) of about 2-3 mm in size (Figure 1d), which in turn coalesce to build up wavy plates (Figure 1e) and subangular blocks, in general highly separated (Figure 1f). The "primary" spheroidal peds seems to be excrements from Lumbricidae (Figure 2b). The dominant voids are compound packing voids (Figure 1d) and large planes, many of them having a horizontalsubhorizontal orientation; the walls of planes are unaccommodated to partially accommodated and their surfaces are undulating to rough (Figures 1e, f; Figure 2c). The microstructure at this depth level varies between granular (Figure $1 d$ ), platy (Figure 1e) and subangular blocky (Figure 1f).

In this same treatment at $5-10 \mathrm{~cm}$ depth, the aggregates are subangular blocks, bigger (about $4 \mathrm{~mm}$ in size) than in the surface level, but moderately or weakly separated (Figures 1g, h, i). The most frequent voids are vughs, commonly with a star shaped morphology (Figure 1i), and planes, which are mostly subvertical (Figure $1 \mathrm{~g})$. The structure at microscopic level should be described as vughy, and it appears as to be the result of a densification of the "primary" 

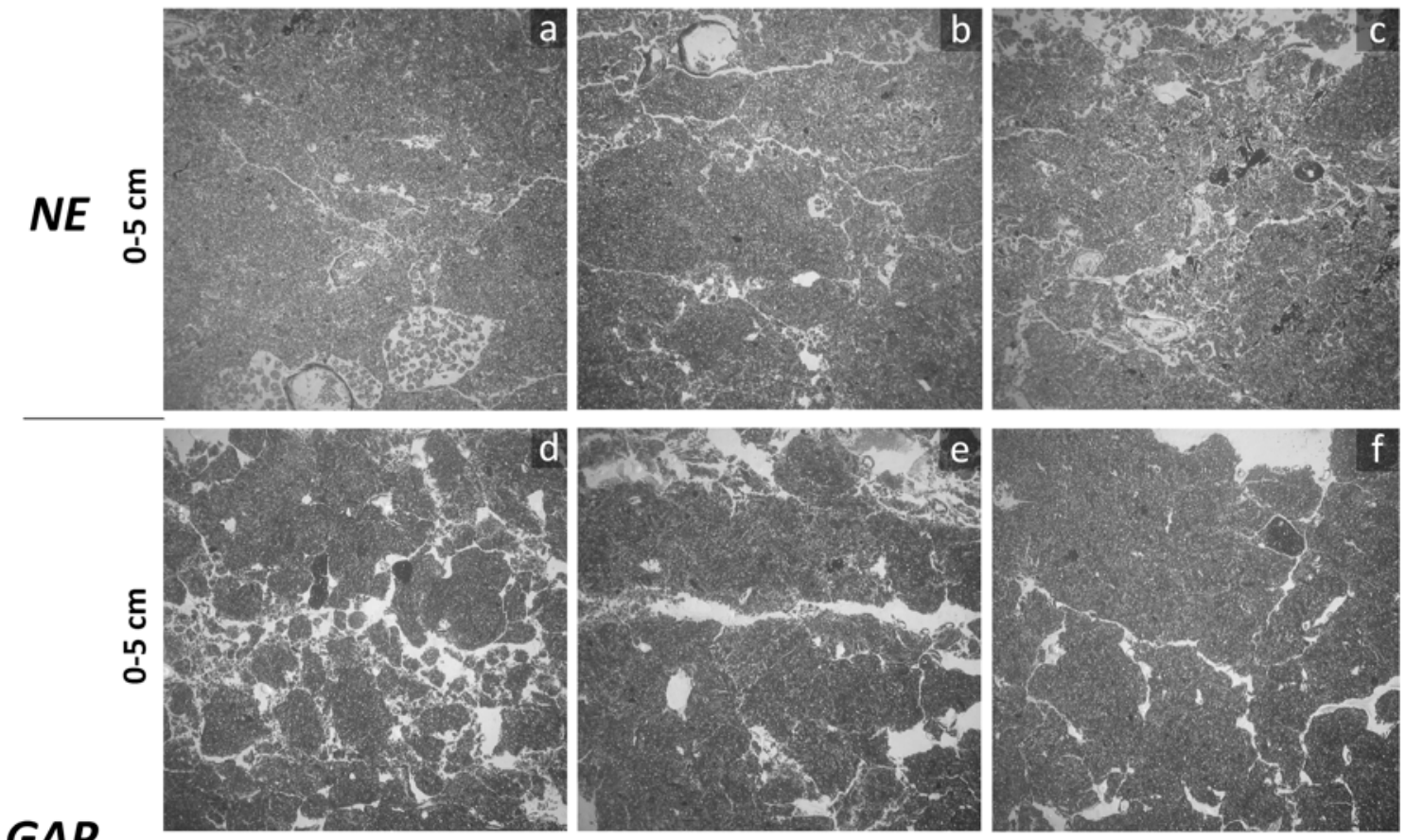

GAP
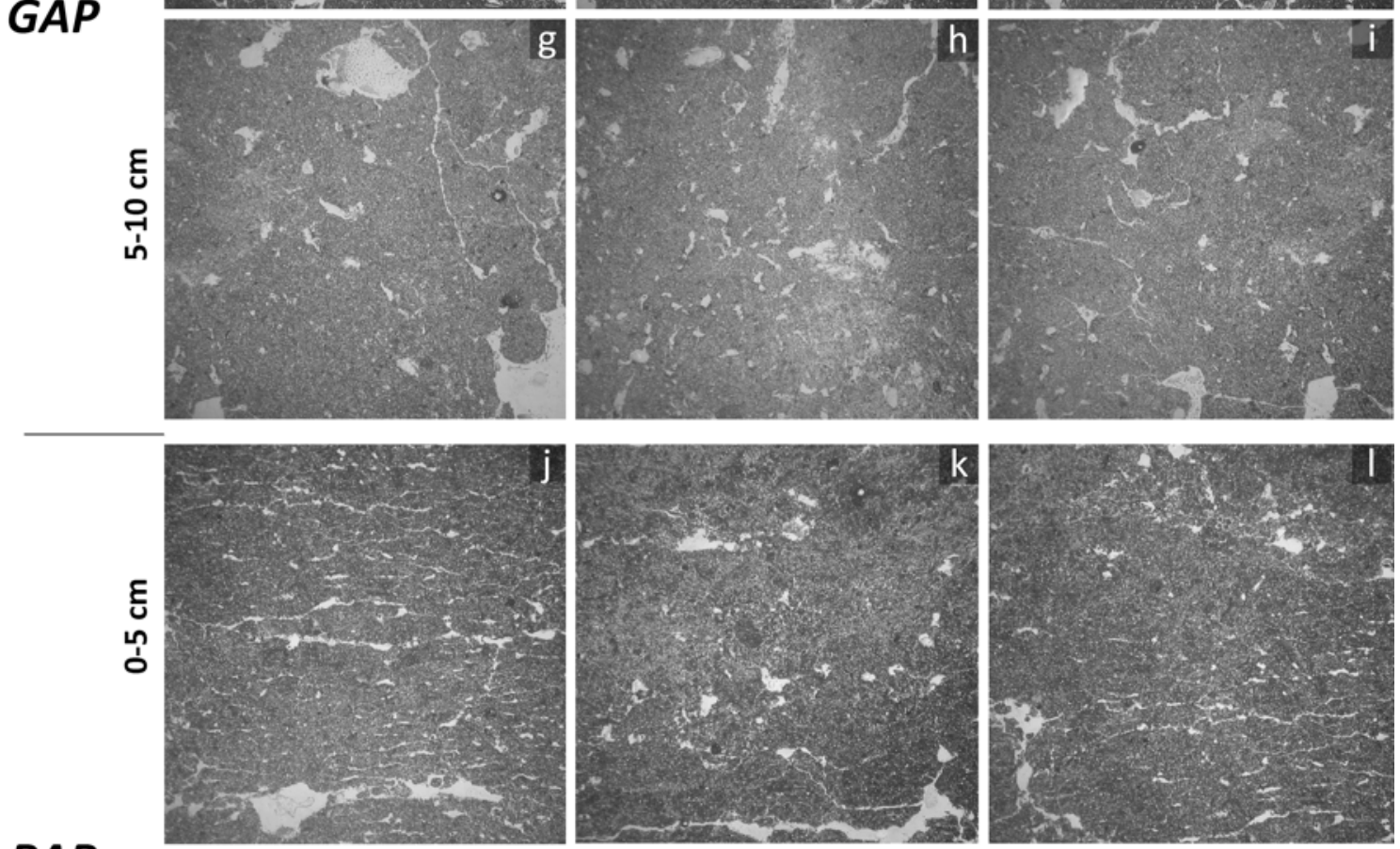

\section{PAP}
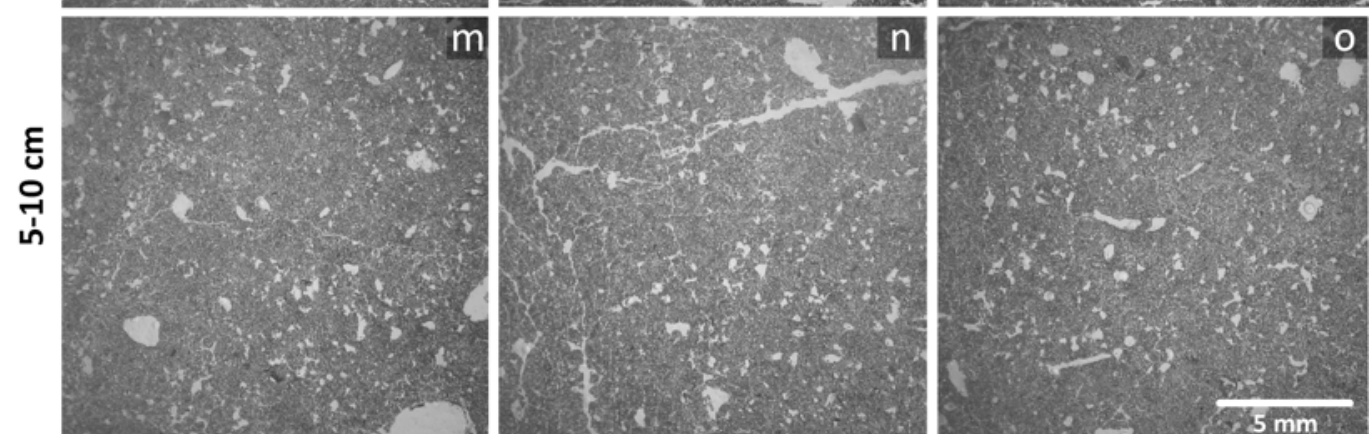

Figure 1. Micrographs of soil thin sections from the A horizon of different treatments in Monte Buey series. NE: Natural environment $(0-5 \mathrm{~cm})$. GAP: Good agricultural practices and PAP: Poor agricultural practices $(0-5 ; 5-10 \mathrm{~cm})$. Topsoil field structure in the reference treatment (NE) was homogeneous between 0-20 cm (Kraemer el al. 2017) and thus only 0-5 cm depth was sampled. 
big granules, less individualized than in the previously described surface level.

In the PAP treatment, at $0-5 \mathrm{~cm}$ the soil particles are arranged in thin, moderately separated, partially to well-accommodated horizontal plates (Figures 1j, k, I). These small plates are commonly arranged in secondary thicker plates, separated by somewhat thicker voids (Figure $1 j)$. The dominant voids are horizontal wavy thin planes; their walls are partially accommodated and undulating. In some sectors the groundmass looks denser, and the porosity is composed by small vughs (Figure 1k). Few channels with excrement infillings and compound packing voids are observed in other areas (Figure 1I).
The microstructure at this soil level is classified as platy.

At 5-10 cm depth of PAP treatment the aggregates are big subangular blocks, moderately separated. Some planar voids related to the walls of these peds are visualized at this level of observation (Figure 1n). Nevertheless the dominant pores are small vughs, around $60 \mu \mathrm{m}$ in size, in the interior of peds (Figures $1 \mathrm{~m}, \mathrm{n}, \mathrm{o}$ ). In several areas, the abundant vughs -many of them starshaped (Figure 2d) - result from the coalescence by compaction of small spheroidal microaggregates (excrements). The microstructure at this soil depth is classified as vughy.
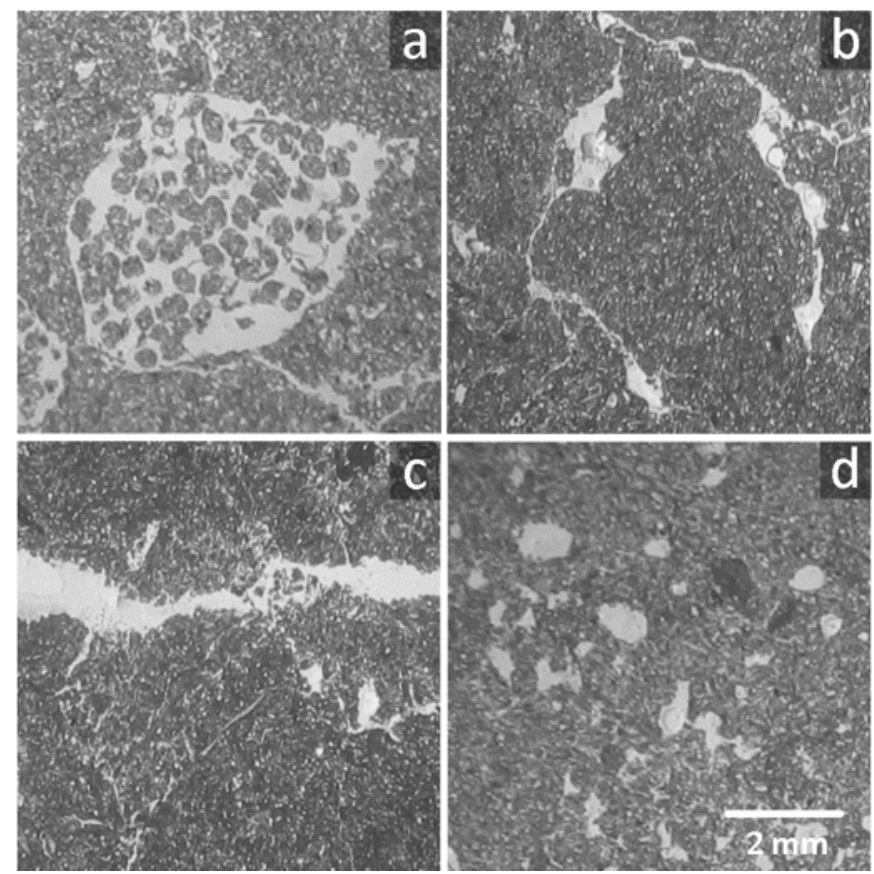

Figure 2. Selected microstructural features from micrographs in Figure 1, at higher magnification; a) (NE, 0-5 cm): tubular pores with excrement infillings; b) (GAP, 0-5 cm): welded big excrements; c) (GAP, 0-5 cm): horizontal plane; the walls are partially accommodated and rather rough; d) (PAP, 5-10 cm): small coalescent excrements and rounded, irregular and starshaped small vughs in a densified groundmass.

\subsection{Pore micromorphometry}

Results on selected porosity size variables and on pore shapes (measured as pore area in both cases) are presented in Table 1. NE and GAP presented similar trends showing statistical differences with PAP $(\mathrm{P}<0.05)$. DM > $50 \mu \mathrm{m}$, $\mathrm{DM}>1000 \mu \mathrm{m}$ and elongated pores were higher in NE and GAP than in PAP. For those both treatments, DM > $50 \mu \mathrm{m}$ was dominated by elongated shapes $(72 \%$ and $65 \%$, for NE and GAP, respectively) while rounded and irregular pores contributed in low proportion to macroporosity.

Conversely, PAP treatment showed a significantly higher rounded and irregular pore area compared to NE and GAP; thus, in PAP 
Table 1. Digital macroporosity (measured as pore area). Total macroporosity (DM $>50 \mu \mathrm{m})$, large macroposity $(>1000 \mu \mathrm{m})$, transmission pores (DM 50-500 $\mu \mathrm{m}$ ) and pore shape for different treatments: natural environment (NE); good agricultural practices (GAP) and poor agricultural practices (PAP) at two sampling depths for the agricultural managements $(0-5 \mathrm{~cm}$ and 5-10 cm). Results are average of five thin sections. Standard deviations are displayed between brackets. Different lowercase letters indicates statistical significances (LSD, P $<0.05)$

\begin{tabular}{|c|c|c|c|c|c|c|c|c|c|c|c|c|c|c|c|c|c|c|c|c|c|c|}
\hline \multirow{3}{*}{ Treatment } & \multirow{3}{*}{$\begin{array}{l}\text { Depth } \\
\text { (cm) }\end{array}$} & \multirow{2}{*}{\multicolumn{9}{|c|}{ Pore size (\%) }} & \multicolumn{12}{|c|}{ Pore shape (\%) } \\
\hline & & & & & & & & & & & \multicolumn{9}{|c|}{ Absolute } & \multicolumn{3}{|c|}{ Relative } \\
\hline & & \multicolumn{3}{|c|}{$\mathrm{DM}>50 \mu \mathrm{m}$} & \multicolumn{3}{|c|}{$\mathrm{DM}>1000 \mu \mathrm{m}$} & \multicolumn{3}{|c|}{ DM 50-500 $\mu \mathrm{m}$} & \multicolumn{3}{|c|}{ Rounded (R) } & \multicolumn{3}{|c|}{ Irregular (I) } & \multicolumn{3}{|c|}{ Elongated (E) } & $\begin{array}{c}\mathrm{R} \\
12.3\end{array}$ & $\begin{array}{c}\text { I } \\
16.1\end{array}$ & $\begin{array}{c}E \\
71.5\end{array}$ \\
\hline \multirow{2}{*}{ GAP } & $0-5$ & 13.9 & (3.2) & \multirow{2}{*}{ A } & 8.3 & (3.0) & \multirow{2}{*}{ A } & 4.4 & $(1.0)$ & $\mathrm{b}$ & 1.4 & $(0.2)$ & c & 2.2 & $(0.3)$ & \multirow[b]{2}{*}{, } & 10.4 & $(2.9)$ & \multirow{2}{*}{ A } & 10.0 & 15.7 & 74.3 \\
\hline & $5-10$ & 9.6 & (2.5) & & 4.1 & (3.3) & & 4.4 & $(0.7)$ & $\mathrm{b}$ & 1.7 & $(0.2)$ & c & 2.6 & $(0.9)$ & & 5.3 & (3.4) & & 17.7 & 27.1 & 55.2 \\
\hline PAP & $0-5$ & 8.8 & (2.1) & & 1.3 & $(1.0)$ & B & 6.6 & $(0.8)$ & a & 3.0 & $(0.3)$ & a & 3.4 & $(0.5)$ & & 2.3 & (2.1) & $\mathrm{E}$ & 34.5 & 39.1 & 26.4 \\
\hline
\end{tabular}

the three different pore shapes are in relatively equivalent proportions. It is to be noted that, according to these quantitative results, PAP at $0-5 \mathrm{~cm}$ depth have the lowest proportion of elongated pores among the samples analyzed, which seems not to fit exactly with its qualitative evaluation. Transmission pores (DM 50-500 $\mu \mathrm{m}$ ) presented the lowest statistical significance $(P=0.04)$ and no differences were found between treatments, though a slightly higher value appear at PAP $(0-5 \mathrm{~cm})$.

As elongated pores presented a major contribution to $\mathrm{DM}>50 \mu \mathrm{m}$ and due to its agronomical significance, other features of this pore shape were further analyzed. Thus, frequency and orientation of elongated pores were related to their size (Tables 2 and 3 ).

Total elongated pore counts were higher in GAP, followed by PAP and NE (Table 2). In general, frequency of elongated pores was related to medium to large pore classes. On the contrary, rounded pores were found mostly in small pore sizes (data not shown). Almost all elongated pores in NE measure between 100-800 $\mu \mathrm{m}$ with only a few pores located in larger pore size ranges. For the agricultural treatments, pore frequency distribution shifted to larger pore sizes. In GAP, a slightly higher proportion of the elongated pores belong to the 1000-3000 $\mu \mathrm{m}$ class, whereas elongated pores in PAP treatment were more uniformely distributed from 400-3000 $\mu \mathrm{m}$ (Table 2).

For all treatments, most of the total elongated porosity, for horizontal, vertical and oblique pores, was found in the 400-800 $\mu \mathrm{m}$ and 1000-3000 $\mu \mathrm{m}$ classes (Table 3). In NE, larger elongated pores $(1000-3000 \mu \mathrm{m})$ are slightly more frequently found within vertical and oblique orientations (Table 3). On the contrary, in GAP and PAP, most of the elongated pores were horizontally oriented and within the larger size category $(1000-3000 \mu \mathrm{m})(70.8 \%$ for GAP and $64.3 \%$ for PAP). However abundance of this

Table 2. Digital macroporosity of elongated pore frequency according pore shape size classes (for GAP and PAP, results correspond to $0-12 \mathrm{~cm}$ soil depth). NE: natural environment; GAP: good agricultural practices; PAP: poor agricultural practices

\begin{tabular}{ccccccccc}
$\begin{array}{c}\text { Pore } \\
\text { frequency }\end{array}$ & \multicolumn{2}{c}{ Elongated pore size $(\boldsymbol{\mu m})$} & & & & & \\
$\mathbf{5 0 - 1 0 0}$ & $\mathbf{1 0 0 - 2 0 0}$ & $\mathbf{2 0 0 - 4 0 0}$ & $\mathbf{4 0 0 - 8 0 0}$ & $\mathbf{8 0 0 - 1 0 0 0}$ & $\mathbf{1 0 0 0 - 3 0 0 0}$ & Total \\
\hline NE & 0 & 15 & 25 & 14 & 3 & 5 & 62 \\
\hline GAP & 0 & 5 & 21 & 30 & 31 & 35 & 121 \\
\hline PAP & 0 & 5 & 15 & 21 & 22 & 23 & 87
\end{tabular}


pore shape between agricultural treatments differs according to the sampling depth. Most of horizontal pores were found at $0-5 \mathrm{~cm}$ in GAP and at $5-10 \mu \mathrm{m}$ in PAP. For other pores sizes this trend is opposite (Table 3). Larger pores (> $800 \mu \mathrm{m}$ ) clearly constitute a higher part of total porosity in GAP compared to PAP, while for smaller sizes it depends on the depth considered.
From this analysis, the results showed that horizontal pores are within the larger sizes while vertical and oblique elongated pores tends to be distributed more homogeneously among different sizes but differs according treatment and sampling depth.

Table 3. Digital macroporosity. Absolute and relative pore orientation percentage for elongated pore shape according size classes and sampling depth. NE: natural environment; GAP: good agricultural practices; PAP: poor agricultural practices (PAP)

\begin{tabular}{|c|c|c|c|c|c|c|c|c|c|c|c|c|}
\hline \multirow{2}{*}{$\begin{array}{c}\text { Management } \\
\text { Treatment }\end{array}$} & \multirow{2}{*}{$\begin{array}{l}\text { Depth } \\
\text { (cm) }\end{array}$} & \multirow{2}{*}{$\begin{array}{c}\text { Pore } \\
\text { orientation }\end{array}$} & \multicolumn{10}{|c|}{ Pore size $(\mu \mathrm{m})$} \\
\hline & & & $100-200$ & & $200-400$ & & $400-800$ & & $800-1000$ & & $1000-3 c$ & \\
\hline & & & $\begin{array}{l}\text { Total } \\
(\%)\end{array}$ & Relative & Total & Relative & Total & Relative & Total & Relative & Total & Relative \\
\hline \multirow[b]{2}{*}{$N E$} & \multirow[b]{2}{*}{$0-5$} & Horizontal & 0.08 & 0.90 & 0.36 & 4.82 & 1.04 & 10.87 & 0.64 & 5.44 & 2.19 & 29.76 \\
\hline & & $\begin{array}{c}\text { Vertical + } \\
\text { Oblique }\end{array}$ & 0.12 & 1.40 & 0.50 & 6.22 & 0.87 & 7.71 & 0.58 & 6.16 & 2.90 & 26.72 \\
\hline \multirow{4}{*}{$G A P$} & \multirow[b]{2}{*}{$0-5$} & Horizontal & 0.02 & 0.20 & 0.29 & 3.18 & 0.46 & 4.49 & 0.12 & 0.87 & 5.57 & 51.46 \\
\hline & & $\begin{array}{c}\text { Vertical + } \\
\text { Oblique }\end{array}$ & 0.06 & 0.65 & 0.46 & 4.46 & 1.19 & 10.95 & 0.82 & 10.47 & 1.41 & 13.25 \\
\hline & \multirow[b]{2}{*}{$5-10$} & Horizontal & 0.02 & 0.25 & 0.24 & 4.09 & 0.32 & 5.31 & 0.12 & 4.17 & 1.49 & 19.39 \\
\hline & & $\begin{array}{c}\text { Vertical + } \\
\text { Oblique }\end{array}$ & 0.04 & 0.75 & 0.45 & 8.34 & 0.89 & 18.92 & 0.54 & 9.06 & 1.21 & 29.72 \\
\hline \multirow{4}{*}{$P A P$} & \multirow[b]{2}{*}{$0-5$} & Horizontal & 0.03 & 1.70 & 0.13 & 6.36 & 0.31 & 18.93 & 0.07 & 2.31 & 0.66 & 13.31 \\
\hline & & $\begin{array}{c}\text { Vertical + } \\
\text { Oblique }\end{array}$ & 0.04 & 2.32 & 0.18 & 11.54 & 0.32 & 19.05 & 0.07 & 7.96 & 0.54 & 16.52 \\
\hline & \multirow[b]{2}{*}{$5-10$} & Horizontal & 0.02 & 0.89 & 0.09 & 3.61 & 0.31 & 11.56 & 0.25 & 5.25 & 1.96 & 50.95 \\
\hline & & $\begin{array}{c}\text { Vertical + } \\
\text { Oblique }\end{array}$ & 0.0115 & 0.24 & 0.13 & 7.49 & 0.34 & 17.60 & 0.00 & 0.00 & 0.13 & 2.42 \\
\hline
\end{tabular}

\subsection{Physical and chemical variables}

The results obtained from the measurement of OC, BD and soil porosity by conventional indirect methods were valuable to differentiate the three treatments compared, and confirm the impact of different NT managements on soil properties. Data obtained from these analyses are shown in Table 4.

Total porosity and macroporosity (> $1000 \mu \mathrm{m}$ ) presented an interaction between treatment and depth $(P<0.05)$, macroporosity $(>50 \mu \mathrm{m})$ was affected by treatment and depth factor $(P<0.001)$, whereas BD and TOC were only affected by the treatment factor $(P<0.001)$.
TOC followed the trend NE > GAP > PAP with significant difference between NE and PAP (Table 4). GAP presented higher bulk density (1.34 $\mathrm{Mg} \mathrm{m}^{-3}$ ) than NE and PAP treatments (1.22, $1.25 \mathrm{Mg} \mathrm{m}^{-3}$, respectively). It must be noted that, in both agricultural treatments, and particularly in GAP, BD increased at $10-20 \mathrm{~cm}$ depth. Total porosity showed higher values in NE and GAP and lower values in PAP. Only slight differences between NE and GAP were detected. In both agricultural treatments, total porosity decreased with depth, reaching the lowest values at $10-20 \mathrm{~cm}$ layer. $\mathrm{P}_{\mathrm{Mac}}>50 \mu \mathrm{m}$ showed a clear and significant trend NE > GAP $>$ PAP where 0-5 cm layers presented higher porosity values respect to deeper layers. Higher values of $P_{M a c}>1000 \mu \mathrm{m}$ were also found in the 
Table 4. Mean bulk density (BD), total organic carbon (TOC), total porosity and macroporosity ( $\mathrm{P}_{\mathrm{Mac}}>50 \mu \mathrm{m}$ and $>1000 \mu \mathrm{m}$ ) of different treatments. NE: natural environment, GAP: good agricultural practices, PAP: poor agricultural practices at three depths $(0-5,5-10,10-20 \mathrm{~cm})$. WRC: Water retention curve. Uppercase letter indicates significant differences among management treatments; lowercase case letter indicates significant differences among management treatment $x$ depth interaction (LSD, $P<0.05)$. Standard errors are displayed between parenthesis.

\begin{tabular}{|c|c|c|c|c|c|c|c|c|c|c|c|c|c|c|c|c|}
\hline \multirow{3}{*}{ Treatment } & \multirow{3}{*}{$\begin{array}{l}\text { Depth } \\
\text { (cm) }\end{array}$} & \multirow{2}{*}{\multicolumn{2}{|c|}{ BD }} & & \multirow{2}{*}{\multicolumn{3}{|c|}{ TOC }} & \multicolumn{9}{|c|}{ WRC Porosity } \\
\hline & & & & & & & & \multicolumn{3}{|c|}{ Total porosity } & \multicolumn{3}{|c|}{$\mathrm{P}_{\mathrm{Mac}}>50 \mu \mathrm{m}$} & \multicolumn{3}{|c|}{$P_{\text {Mac }}>1000 \mu \mathrm{m}$} \\
\hline & & & $\mathrm{g} \mathrm{cm}^{-3}$ ) & & & $(\%)$ & & $\left(m^{3} m^{-3}\right)$ & & & & & & & & \\
\hline \multirow{3}{*}{$N E$} & $0-5$ & 1.00 & $(0.03)$ & \multirow{3}{*}{ B } & 2.22 & $(0.57)$ & \multirow{3}{*}{ A } & 0.66 & $(0.03)$ & $d$ & 0.35 & $(0.07)$ & \multirow{3}{*}{ A } & 0.0516 & $(0.256)$ & $d$ \\
\hline & $5-10$ & 1.32 & $(0.00)$ & & 2.03 & $(0.46)$ & & 0.67 & $(0.06)$ & $d$ & 0.20 & $(0.04)$ & & 0.0076 & $(0.003)$ & $a b c$ \\
\hline & $10-20$ & 1.37 & $(0.01)$ & & 1.83 & $(0.10)$ & & 0.54 & $(0.03)$ & $\mathrm{bc}$ & 0.12 & $(0.07)$ & & 0.0029 & $(0.002)$ & a \\
\hline \multirow{3}{*}{ GAP } & $0-5$ & 1.29 & $(0.01)$ & \multirow{3}{*}{ A } & 1.44 & $(0.72)$ & \multirow{3}{*}{$A B$} & 0.70 & $(0.07)$ & $d$ & 0.22 & $(0.07)$ & \multirow{3}{*}{ B } & 0.0164 & $(0.009)$ & bcd \\
\hline & $5-10$ & 1.52 & $(0.01)$ & & 1.49 & $(0.18)$ & & 0.55 & $(0.05)$ & c & 0.12 & $(0.03)$ & & 0.0065 & $(0.005)$ & $a b$ \\
\hline & $10-20$ & 1.56 & $(0.00)$ & & 1.81 & $(0.63)$ & & 0.44 & $(0.04)$ & a & 0.15 & $(0.03)$ & & 0.0217 & $(0.015)$ & $\mathrm{cd}$ \\
\hline \multirow{3}{*}{ PAP } & $0-5$ & 1.19 & 0.02 & \multirow{3}{*}{$B$} & 1.30 & $(0.90)$ & \multirow{3}{*}{ B } & 0.50 & $(0.08)$ & $a b c$ & 0.15 & $(0.08)$ & \multirow{3}{*}{ C } & 0.0031 & $(0.002)$ & $a$ \\
\hline & $5-10$ & 1.44 & 0.02 & & 1.32 & $(0.41)$ & & 0.48 & $(0.04)$ & $a b$ & 0.08 & $(0.02)$ & & 0.0037 & (0.001) & a \\
\hline & $10-20$ & 1.48 & 0.01 & & 0.94 & $(0.16)$ & & 0.44 & $(0.01)$ & $a$ & 0.09 & $(0.02)$ & & 0.0042 & $(0.003)$ & a \\
\hline
\end{tabular}

upper layer $(0-5 \mathrm{~cm})$ of NE and GAP, and in the deeper layer $(10-20 \mathrm{~cm})$ of the GAP treatment. Overall PAP presented the lower $\mathrm{P}_{\text {Mac }}>1000 \mu \mathrm{m}$ values.

Mean aggregate stability measured the by Le Bissonnais method at $0-15 \mathrm{~cm}$ presented significant differences between all treatments following NE > GAP > PAP (Figure 3a). Hydraulic conductivity was clearly higher in NE compared to both agricultural treatments while no statistical differences were detected for Ks between GAP and PAP (Figure 3b).

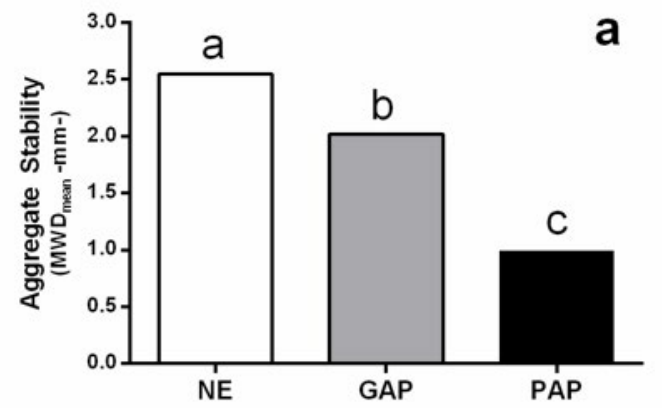

3.4. Association between physical and chemical variables and micromorphometric porosity

Principal component analysis (PCA) based on mean soil physical and chemical variables and micromorphometric variables showed a clear grouping of treatments across PC1 (Figure 4). This axe, which retained $67.7 \%$ of the total variability, was explained mainly by elongated pores, aggregate stability and vertical and oblique pores < $400 \mu \mathrm{m}$. PC2 retained $24.0 \%$ of the total variability to reach $92 \%$ of the total variability in the first two axes. Main variables of this axe consisted in OC and BD. As it was

Figure 3. a) Mean aggregate stability measured by the Le Bissonnais method (1996) and b) saturated hydraulic conductivity (Ks) for each treatment. NE: natural environment; GAP: good agricultural practices; PAP: poor agricultural practices at three depths $(0-5,5-10,10-20 \mathrm{~cm})$. Different letters indicate significant differences (LSD, $P<0.05)$. 
presented in ANOVA analyses (Table 1), different pore shapes were related to each agricultural treatment (elongated for GAP and rounded for $\mathrm{PAP}$ ). In this sense the discrimination ability of $\mathrm{DM}>50 \mu \mathrm{m}$ was lower compared to pores shape and orientation (Figure 4). Aggregate stability was mainly associated with elongated pores in their two size classes (> 400 and $<400 \mu \mathrm{m}$ ) and with vertical and oblique orientations.
BD presented negative correlations with $\mathrm{Ks}$ (r:-0.77) and TOC (r:-0.86) and positive with large horizontal elongated pores $(r: 0.88)$. Ks present low correlations with digital porosity variables but it was grouped with NE treatment. $\mathrm{P}_{\mathrm{Mac}}>1000 \mu \mathrm{m}$ was associated with vertical and oblique elongated pores, $\mathrm{DM}>50 \mu \mathrm{m}$ and with AS.

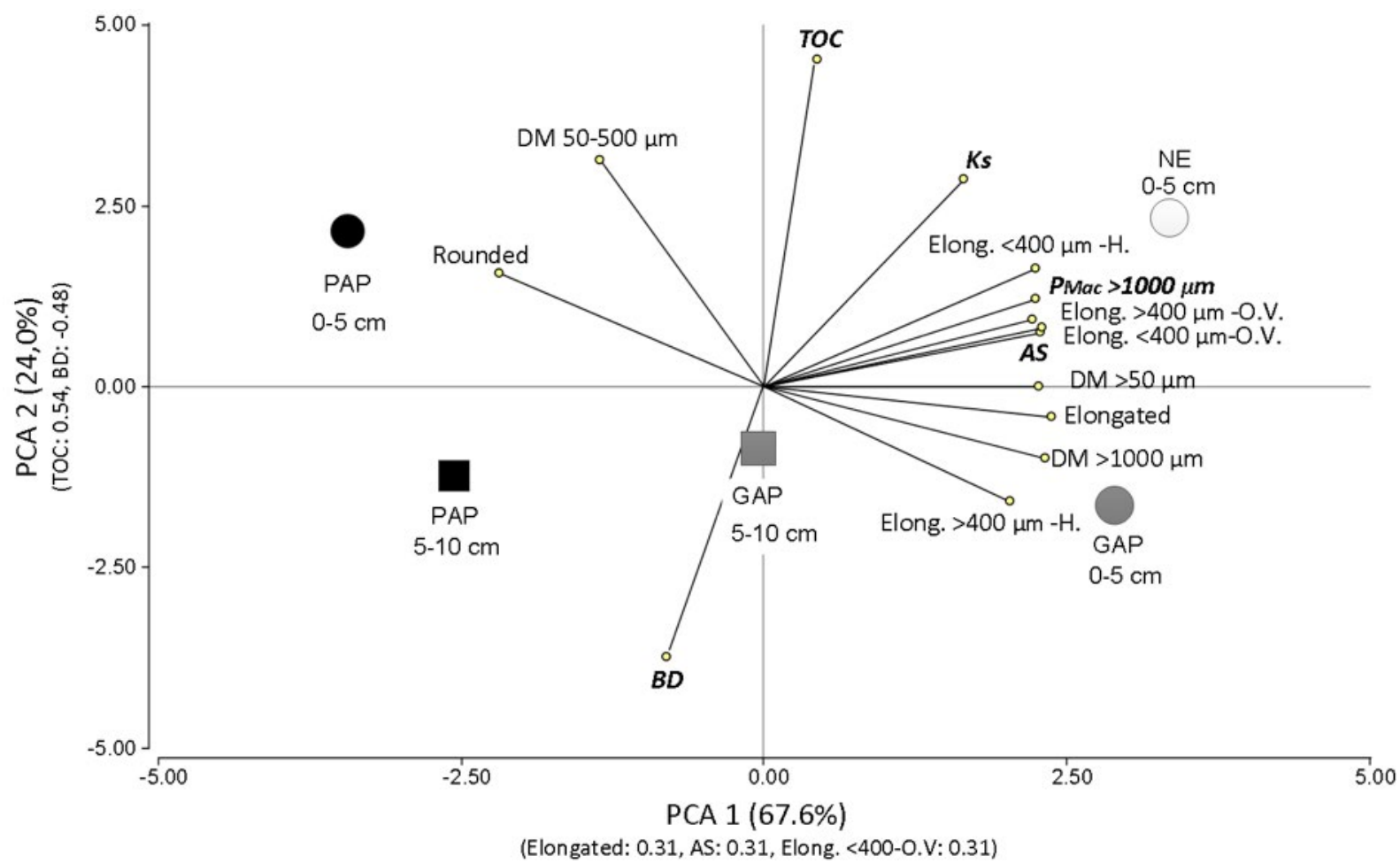

Figure 4. Scores on the first (PCA1) and second axes (PCA2) of the principal component analysis. NE: natural environment; GAP: good agricultural practices; PAP: poor agricultural practices. (AS: aggregate stability; BD: bulk density; TOC: total organic carbon; Ks: saturated hydraulic conductivity; $\mathrm{H}$ : pores horizontally oriented; O.V: pores with oblique and vertical orientation). The length of the vectors represents the magnitude of the representation of each variable for each component and the angles between the variables indicate the correlation between them. Angles of $90^{\circ}$ between two variables indicate that they are not correlated. Below both axes principal autovectors are presented in parenthesis.

\section{Discussion}

Textural and mineralogical differences between treatments are low (Kraemer 2015) and fall within the variability range of this series, although they could have been eventually influenced by agricultural management. However the main drivers explaining TOC and microstructure differences are clearly management variables such as cropping intensity, crop diversification and years under no-till.

The topsoil microstructure differs remarkably between the three treatments compared in this study. Although a difference between NE and the agricultural treatments was expected, differences were also particularly clear between GAP and PAP. In both treatments under NT, the anisotropy in the upper twelve centimeters of the soil was noticeable. The formation of 
soil structure is the result of the actions and interactions of numerous physical, chemical and biological factors with intricate feedback mechanisms (Six et al. 2004) and therefore the evolution of structure and porosity with different cropping intensities is quite complex to understand.

The results of the two methods used to quantify porosity (core samples and thin sections) were in concordance and showed the same trend between treatments (Tables 1 and 4). This was also supported by a reasonable determination coefficient $\left(R^{2}\right.$ : 0.66; $\left.P<0.09\right)$ between $\mathrm{DM}>50 \mu \mathrm{m}$ and $\mathrm{P}_{\mathrm{Mac}}>50 \mu \mathrm{m}$ (Figure 5). This association was close to the 1:1 line. However, macroporosity measured by WRC was $40 \%$ higher than digital macroporosity. Association between $\mathrm{DM}>50 \mu \mathrm{m}$ and total porosity showed a determination coefficient of 0.99 (Figure 5). However, the 1:1 line was lost as consequence of different porosity size ranges accounted by each method. As intrinsic soil characteristics (texture, mineralogy) and microporosity $(<50 \mu \mathrm{m})$ did not differ substantially between treatments (Kraemer 2015), differences in total porosity could be related to changes in macroporosity, which were coincidently reflected by the pressure plate method and micromorphometric analyses.
Thus, micromorphometry gave sound results and allowed the discussion of further porosity variables.

These porosity variables measured by image analyses appeared statistically more sensible than $\mathrm{OC}, \mathrm{BD}$ or $\mathrm{Ks}$ to evaluate differences between treatments (Figure 4). In this sense, pore orientation, in particular vertical and oblique pores, retained more variability in the PCA than DM > $50 \mu \mathrm{m}$ (Figure 5). Moreover, they presented a close association with aggregate stability, one of the most sensitive soil properties to assess changes in agricultural practices (Perfect et al. 1990). These associations could be linked to biological agents as plant roots, earthworms, bacteria and fungi leading to stability improvement by exudates, glomalin, ergosterol and organic carbon fractions at different scales (Lavelle et al. 2004; Carrizo et al. 2015; Duchicela et al. 2013).

In this study, DM > $50 \mu \mathrm{m}$ and $\mathrm{DM}>1000 \mu \mathrm{m}$ showed higher values in NE and GAP compared to PAP. According to the criteria proposed by Pagliai (1988) for micromorphometric analyses, $\mathrm{NE}$ and GAP from $0-10 \mathrm{~cm}$ are classified as moderately porous (macroporosity between $10-25 \%$ ) while PAP porosity corresponds to the

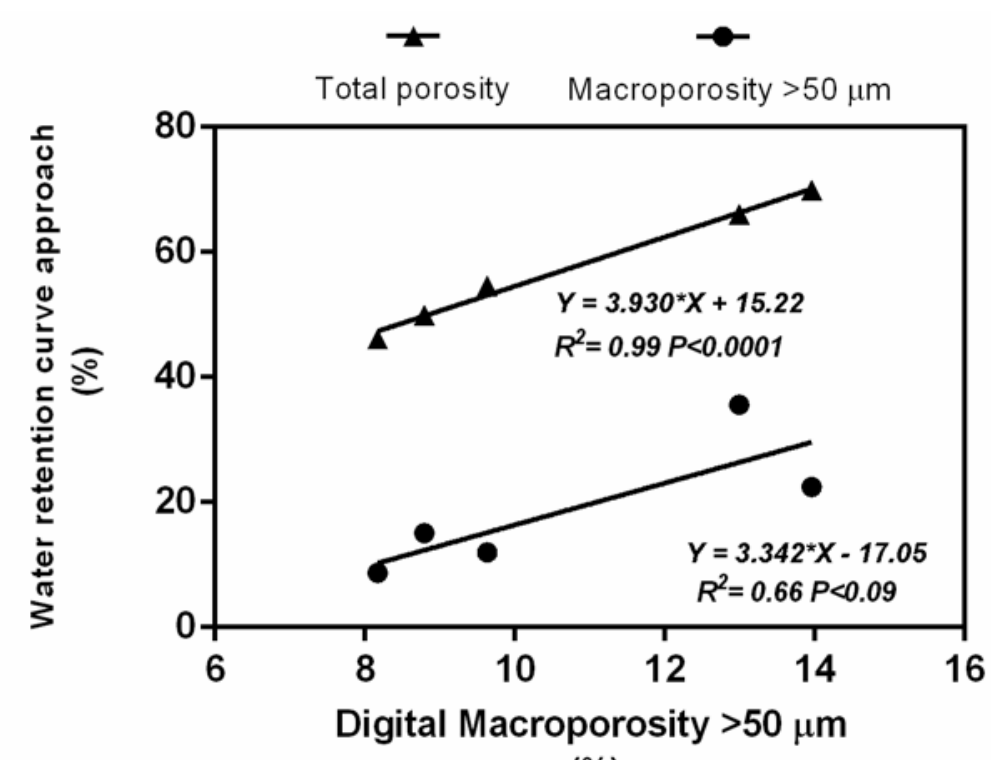

(\%)

Figure 5. Regression between digital macroporosity $>50 \mu \mathrm{m}$ and the total porosity and macroporosity $>50 \mu \mathrm{m}$. 
compact category (0-10\%). Several authors have observed a reduction in macroporosity under NT compared to natural situations using micromorphometric analyses (Pagliai et al. 1983; VandenBygaart et al. 1999). Concordance between NE and GAP could be explained by the longterm cultivation under NT in GAP treatment (28 years). Recent studies suggest that after nearly 15 years, NT plots could overcome settling or compaction through the development of biological pores, and could present many similarities with uncropped soils (Sasal et al. 2017b). Although DM > $50 \mu \mathrm{m}$ from GAP was similar to NE, differences in pore architectures were evident between both situations (Tables 1, 2, 3; Figures 1, 2).

Elongated pores explained most of the total digital macroporosity (DM > $50 \mu \mathrm{m}$ ) and the differences between treatments, particularly in large pore size classes (Tables 1 and 2), which is in accordance with other studies (Pagliai et al. 1983; Castiglioni and Morrás 2007; Fernández et al. 2012; Morrás et al. 2008). As shown in the PCA, the proportion of elongated pores (higher in NE and GAP) was one of the main variables that allowed the discrimination between the three treatments (Figure 4). The number of elongated pores and their distribution were also different between treatments. Pachepsky et al. (1996) also found that management practices affected the number and the area of large elongated pores mainly in large pores.

Costantini et al. (2006) suggested that in soils of vineyards and olive groves, the proportion of elongated and irregular pores should be at least $80 \%$ to reach an optimal drainage. In this study, NE and GAP presented a proportion of irregular and elongated pores higher than that threshold (88\%, 86\% respectively) while PAP presented a lower proportion (69\%). In the NE treatment, that threshold is associated with high proportion of vertical and oblique pores, relative low $\mathrm{BD}$, high aggregate stability and high $\mathrm{Ks}$. These adequate physical variables are in turn related to the high OC content and to the abundant biological features observed in thin sections (Figures 1,2) which are due to the lack of disturbance and the presences of active roots during all year (Räty et al. 2010; Novelli et al. 2011).
Quantification of transmission pores (50-500 $\mu \mathrm{m})$ showed only small differences between treatments (Table 1). These findings agree with those of Rasa et al. (2012) and Pastorelli et al. (2013) that detected no differences in this pore size range between treatments in Cambisols, including NT, minimum tillage, grazing and a natural environment. On the contrary, Pagliai and de Nobili (1993) found significant differences between minimum tillage, ripper subsoiling and conventional deep ploughing. It must be noted that in the present study and in the works of Pastorelli et al. (2013) and Rasa et al. (2012), the treatments studied imply a lower disruption energy of soil structure compared to ripper subsoiling and conventional deep ploughing.

In this study, micromorphological analyses provided sound evidence about the role and the intensity of biological activity on the development of soil structure in the three treatments. In NE, abundant features such as excrements and channels indicate an intense biological activity, thus giving rise to a "bio-built" soil structure (Morrás et al. 2012; Morrás 2014). In GAP, the biological activity appears also quite intense, though differing from NE; on one hand, excrements are mostly bigger than in NE, thus suggesting a different fauna; on the other hand, they are evidently affected by some compaction caused by cultivation. In PAP, fauna activity is less intense, tubular infillings are disrupted and the small excrements appear mostly compacted. Optical observations also clearly show that the morphology and evolution of aggregates and voids differ between the three treatments. In NE, some plates, moderately developed and internally highly porous are observed at $0-5 \mathrm{~cm}$ depth. In GAP, platy aggregates are more frequent and better developed than in NE, but they look dense, resulting from the juxtaposition and packing of big granules of biological origin. In PAP, the dominance of small plates separated by thin planes is notorious, thus forming a denser platy microstructure, only slightly disturbed by biological activity (Figure 1). These results coincide with the usual observation of platy structures in different Mollisols under NT in the Pampean region (Álvarez et al. 2004; 2014; Morrás et al. 2004; Lozano 2015; Sasal et al. 2017b; Kraemer et al. 2017), though in this study their different morphology and 
development appear related to differences in their management. Image analysis confirms that GAP presented a few large elongated pores with horizontal orientation, mainly in the topsoil $(0-5 \mathrm{~cm})$, while horizontal pores in PAP appear distributed in different pore sizes mostly in $5-10 \mathrm{~cm}$ layer (Table 3). Nevertheless, it is interesting that morphological evaluation of thin sections from PAP at $0-5 \mathrm{~cm}$ depth suggests a dominance of thin plane pores, and thus microstructure is qualified as platy (Figures $1 \mathrm{j}, \mathrm{k}$, I), while micromorphometry shows that this layer has the lowest proportion of elongated pores among the samples analyzed (Table 2). These different results, which would be based on the particularities of each procedure (synthetic appreciation of relevant morphological units in the qualitative visual description and area measurements in the digital quantification), are indicative of a useful complementation between both methods.

Concerning the $5-10 \mathrm{~cm}$ layer, a soil densification in both agricultural treatments is evident from the morphology. Although the microstructure should be described as vughy in both cases, the morphology and size of aggregates and pores differs between them. In GAP, a compaction of rounded microaggregates is observed, giving rise to rather large vughs and some planes, while PAP is characterized by a high number of rather small vughs. In this study, GAP and PAP presented a BD exceeding the average $\mathrm{BD}$ for the Pampa region (1.2-1.3 $\mathrm{Mg} \mathrm{m}^{-3}$ ) (Álvarez and Steinbach 2009) as well as the critical threshold of $1.4 \mathrm{Mg} \mathrm{m}^{-3}$ proposed by Jones (1983) for silty soils. The formation of platy structures at the upper $0-5 \mathrm{~cm}$ layer in GAP may be related to this higher densification at a deeper layer. Sasal et al. (2017a) have recently suggested the formation of platy structures under NT as consequence of a previous compaction of deeper soil layers (older plough pan). In the GAP treatment, and although biological activity and several soil parameters are better than in PAP, its higher degree of intensification is accompanied by an increase in machinery traffic. Thus, in spite of the improvement of several soil properties produced by this agriculture management, the increment of compaction produced by traffic in the subsurface would subsequently promote the development of plates at the topsoil.
Inversely, the occurrence of platy structures in the PAP treatment may be related to the simplification of the crop sequences, which paradoxically would increase the impact of lower traffic intensity. As mentioned by Pittelkow et al. (2015), the lack of crop rotations could lead to both SOC and productivity losses even under NT. Aggregate stability is higly dependent on the OM content, while macropore features and water flow depend on aggregate stability as it controls the risk of structural collapse (Peng et al. 2015). In the Pampa region, no-tilled soils with a high proportion of soybean in the crop sequences are sparsely covered by crop residues, subsurface horizons show a poor distribution of root systems and the soil experiences long fallow periods (Sasal et al. 2017b). In this region, Sasal et al. (2009) found the lowest values of macropores (> $50 \mu \mathrm{m})$ in no-tilled soils with soybean monoculture. In our PAP treatment, the reduction of the macroporosity (both methods) and the higher proportion of horizontal pores are also associated with the high soybean/total crops ratio (0.71), leading to a low TOC content and thus to a lower aggregate stability (Table 4, Figure 3). In this study, NE and GAP presented highly stable aggregates according to the categories proposed by Le Bissonnais (1996) while PAP was included in the medium stability category (Figure 3 ). The lower macroporosity and aggregate stability values found in PAP under NT could thus reflect the inability of silty soils to counteract compaction in the absence of a high biological activity (Taboada et al. 1998; Morrás et al. 2012; Sasal et al. 2017a).

On the other hand, the higher porosity in NE and GAP, mainly in the large pore sizes, and the relationship between $\mathrm{P}_{\text {Mac }}(>1000 \mu \mathrm{m})$ with oblique and vertical pores and AS (Figure 5), also suggest the key role of root density on structure formation. NE and GAP presented a higher ISI index $(1,0.64$, respectively) than PAP (0.49), indicating the presence of live roots throughout the year. This pore size is considered highly fragile and therefore the evidence of a positive relationship with AS can be considered as an indication of the persistance of these pores. In addition, Pagliai (1987) indicated that pores larger than $500 \mu \mathrm{m}$ can act on root penetration and water movement, especially in soils with fine textures as analyzed here. 
Although GAP treatment presented higher macroporosity by direct and indirect methods, as well higher AS and OC, no differences were found in Ks between GAP and PAP. Contrary to the reports of Pagliai et al. (2004) and Fox et al. (2004), no association was found in this work between Ks and elongated pores. According to the thresholds proposed by Reynolds et al. (2008) and Castellini et al. (2013), all Ks measures in both treatments were included into the optimal range. This supports the findings that in many plots with platy structures water movement was not impaired (Cavalieri et al. 2009; Kraemer 2015). Clearly further research is needed to understand cropping intensity effects on soil structure features and the influence of platy structures on water movement.

Finally, some inconsistences between bulk density values and porosity results obtained by micromorphometry and the soil water retention curve approach should be noted (Tables 1 and 4). We do not have an explanation for these differences. The replication number in all methods used here seems to be reasonable. In the case of agricultural management, this inconsistency may be explained by the influence of different type, abundance and location of platy structure on bulk density determinations. Thus for example, in soils with an abundance of platy structures, Sasal et al. (2006) obtained different bulk density results according to the orientation of sampling cores (vertical versus horizontal).

\section{Conclusions}

Field and micromorphological analyses have shown that agriculture management under no-tillage promotes the development of platy microstructures in the topsoil, and raised questions and studies about physical properties and water dynamics under this system of cultivation. The microscopic study performed here was carried out in the A horizons of two contrasting no-till treatments that showed platy microstructures in both treatments: a highly intensified cropping sequence including corn and wheat as well as soybean (GAP) and a simplified crop sequence with predominance of soybean (PAP). A non-cultivated soil treatment (NE) included in this study as a reference helped to show the modifications produced by soil cultivation under different agricultural managements.

Results of the morphological analysis revealed important differences between both agricultural treatments. In the surface layer in GAP, platy aggregates are thick and result from the cohesion of rounded microaggregates of biological origin; in PAP they are thin and dense, resulting mostly from compaction of individual soil particles derived from mechanical destruction of aggregates during the previous conventional tillage management. A soil densification is evident in both agricultural treatments at $5-10 \mathrm{~cm}$ depth, although the morphology and size of aggregates and pores also differ between them. On the other hand, micromorphometric analyses have shown differences in total macroporosity as well as in the size, morphology and orientation of macropores between both treatments. Macroporosity values obtained by digital methods were coincidently reflected by the pressure plate method. Porosity variables measured by digital analysis, in particular elongated pores and pore orientation, appear more sensitive than other soil properties (total carbon, aggregate stability, bulk density) to discriminate treatments. Although no-till cultivation led to the formation of platy microstructures and a decrease of soil porosity compared to NE, both agricultural treatments presented optimal values of $\mathrm{Ks}$ and water movement was not impaired. As expected, all morphological and analytical soil variables were better in the NE treatment. In addition, it was interesting to verify that the values of several parameters were close or similar between GAP and NE.

Even when more intensified crop sequences (GAP) increase machinery traffic, which has been reflected by a higher soil bulk density, values of several morphological, physical and chemical soil properties were less impaired compared to PAP with lower cropping intensity. As suggested previously (Morrás et al. 2012), the topsoil microstructure under no-till is the result of mechanical stresses and biological actions that act in opposition to each other. 
In GAP treatments, the higher proportion of graminea in the crop sequence, besides its effect on the development of root biopores, seems to promote a higher faunal activity that effectively counteracts the vertical mechanical compression produced by traffic. These results suggest that, in addition to the known benefits of non-tillage on soil conservation (i.e. erosion control, moisture conservation, etc.), the improvement of various soil properties could be achieved by integrating this method of cultivation with suitable agricultural managements.

\section{REFERENCES}

- Agostini MA, Studdert GA, Domínguez GF, Toun SN. 2013. Intensificación del uso del suelo: Efecto sobre algunas propiedades físicas y el carbono orgánico total. In: Jornadas Argentinas de Conservación de Suelos; 2013 Jul 2-4; Buenos Aires, Argentina.

- Álvarez CR, Fernández PL, Taboada MA. 2012. Relación de la inestabilidad estructural con el manejo y propiedades de los suelos en la región pampeana. Ciencia del Suelo (Argentina) 30(2):173-178.

- Álvarez C, Gutiérrez F, Taboada M, Prystupa P, Ocampo J, Fernández P, Moulin M, Vaccaro H. 2004. Propiedades físicas, químicas y biológicas del suelo bajo distintos manejos en el norte de Buenos Aires. In: Actas del XIX Congreso Argentino de la Ciencia del Suelo; 2004 Jun 22-25; Paraná, Argentina.

- Álvarez R, Steinbach HS. 2009. A review of the effects of tillage systems on some soil physical properties, water content, nitrate availability and crop yield in the Argentine Pampas. Soil Till Res. 104:1-16.

- Álvarez CR, Taboada MA, Perelman S, Morrás HJM. 2014. Topsoil structure in no-tilled soils in the Rolling Pampa, Argentina. Soil Res. http://dx.doi.org/10.1071/ SR13281.

- Austin AT, Pineiro G, González-Polo M. 2006. More is less: agricultural impacts on the $\mathrm{N}$ cycle in Argentina. Biogeochemistry 79:45-60.

- Ball BC, Robertson EAG. 1994. Soil structural and transport properties associated with poor growth of oilseed rape in soil direct drilled when wet. Soil Till Res. 31:119-133.

- Balzarini MG, González L, Tablada M, Casanoves F, Di Rienzo JA, Robledo CW. 2008. Infostat. Manual del Usuario. Córdoba, Argentina: Editorial Brujas.

- Bauder JW, Randall GW, Swann JB. 1981. Effect of four continuous tillage systems on mechanical impedance of a clay loam soil. Soil Sci Soc Am J. 44:802-806.

- Blake GR, Hartge KH. 1986. Bulk density. In: Klute A, editor. Methods of Soil Analysis Part 1. Physical and Minerological Methods. Madison, WI: ASA, SSSA. p. 363-376.

- Bonel B, Morrás H, Bisaro V. 2005. Modificaciones de la microestructura y la materia orgánica en un suelo Argiudol bajo distintas condiciones de cultivo y conservación. Ciencia del Suelo (Argentina). 23:1-12.

- Bouma J, Jongerius A, Boersma O, Jager A, Schoonderbeek D. 1977. The function of different types of macropores during saturated flow through four swelling soil horizons. Soil Sci Soc Am J. 41:945-950. 
- Carrizo E, Alesso CA, Cosentino D, Imhoff S. 2015. Aggregation agents and structural stability in soils with different texture and organic carbon. Sci Agric. 72(1):7582.

- Castellini M, Pirastru M, Niedda M, Ventrell D. 2013. Comparing physical quality of tilled and no-tilled soils in an almond orchard in southern Italy. Italian J Agron. 8:20.

- Castiglioni MG, Morrás HJM. 2007. Uso del análisis digital de imágenes para el estudio de la porosidad de la zona no saturada de Argiudoles de Argentina. In: Giráldez Cervera JV, Jiménez Hornero FJ, editors. Estudios de la Zona no Saturada del Suelo. Vol. 7. p. 83-88.

- Castiglioni M, Morrás H, Santanatoglia O, Altinier M, Tessier D. 2007. Movimiento del agua edáfica en Argiudoles de la Pampa Ondulada con diferente mineralogía de arcillas. Ciencia del Suelo (Argentina). 25:109-121.

- Cavalieri KMV, Silva AP, Tormena CA, Leão TP, Dexter AR, Hakansson I. 2009. Long-term effects of no-tillage on dynamic soil physical properties in a Rhodic Ferralsol in Paraná, Brazil. Soil Till Res. 103:158-164.

- Caviglia, OP, Andrade FH. 2010. Sustainable intensification of agriculture in the argentinean pampas: capture and use efficiency of environmental resources. Am J Plant Sci Biotechnol. 3:1-8.

- Chagas C, Marelli H, Santanatoglia O. 1994. Propiedades físicas y contenido hídrico de un Argiudol típico bajo tres sistemas de labranza. Ciencia del Suelo (Argentina) 12:11-16.

- Costantini E, Pellegrini S, Vignozzi N, Barbetti R. 2006. Micromorphological characterization and monitoring of internal drainage in soils of vineyards and olive groves in central Italy. Geoderma 131:388-403.

- Derpsch R. 2002. Sustainable Agriculture. In: Saturnino HM, Landers JN, editors. The Environment and Zero Tillage. Brasília: Associação de Plantio Direto no Cerrado. p. 31-52.

- Derpsch R, Franzluebbers AJ, Duiker SW, Koeller K, Friedrich T, Sturny WG, Sá JCM, Weiss K. 2014. Why do we need to standardize no-tillage research? Soil Till Res. 137:16-22.

- Derpsch R, Friedrich T, Kassam A, Li H. 2010. Current status of adoption of no-till farming in the world and some of its main benefits. Int J Agric Biol Eng. 3:1-26.

- Di Rienzo JA, Casanoves F, Balzarini MG, González L, Tablada M, Robledo CW. 2012. InfoStat versión 2012. Grupo InfoStat, FCA, Universidad Nacional de Córdoba, Argentina. URL http://www.infostat.com.ar.

- Duchicela J, Sullivan T, Bontti E, Bever J. 2013. Soil aggregate stability increase is strongly related to fungal community succession along an abandoned agricultural field chronosequence in the Bolivian Altiplano. J Appl Ecol. 50:1266-1273.
- Duval ME, Galantini JA, Iglesias JO, Canelo S Martínez JM, Wall L. 2013. Analysis of organic fractions as indicators of soil quality under natural and cultivated systems. Soil Till Res. 131:11-19.

- Duval M, Galantini J, Martínez J, López F, Wall L. 2015. Evaluación de la calidad edáfica de los suelos de la región pampeana: efectos de las prácticas de manejo. Revista de Investigaciones de la Facultad de Ciencias Agrarias-UNR 0(25):033-043.

- Fernández PL, Kraemer FB, Morrás HJM. 2012. Porosidad y microestructura superficial de un Argiudol típico en distintos momentos bajo diferentes manejos agropecuarios. In: Actas del XIX Congreso Latinoamericano de la Ciencia del suelo, AACS; 2012 Apr 16-20; Mar del Plata, Argentina.

- Figuerola EL, Guerrero LD, Rosa SM, Simonetti L, Duval ME, Galantini JA, Bedano JC, Wall LG, Erijman L. 2012. Bacterial indicator of agricultural management for soil under no-till crop production. PLoS One 7(11):e51075.

- Fox D, Bryan R, Fox C. 2004. Changes in pore characteristics with depth for structural crusts. Geoderma 120:109-120.

- Greenland DJ. 1977. Soil damage by intensive arable cultivation: temporary or permanent? Phil Trans Royal Soc London 281:193-208.

- Imhoff S, Ghiberto PJ, Grioni A, Gay JP. 2010. Porosity Characterization of Argiudolls under Different Management Systems in the Argentine Flat Pampa. Geoderma 158:268-274.

- Jones CA. 1983. Effect of Soil Texture on Critical Bulk Densities for Root Growth. Soil Sci Soc Am J. 47:1208121.

- Kirkegaard JA, Hunt JR. 2010. Increasing productivity by matching farming system management and genotype in water-limited environments. J Exp Bot. 61:4129-4143.

- Klute A, Dirksen C. 1986. Hydraulic conductivity and diffusivity: laboratory methods. In: Klute A, editor. Methods of Soil Analysis. Part 1. Physical and Mineralogical Methods, 2nd ed. Agron. Monogr. 9. Madison, WI: ASA SSSA. p. $687-734$

- Kraemer FB. 2015. Influencia de la granulometría y la mineralogía en el comportamiento hidro-físico y estructural en suelos con distinta intensidad y secuencia de cultivos bajo siembra directa. PhD Thesis. Escuela para Graduados Alberto Soriano, Facultad de Agronomía, Universidad de Buenos Aires, Argentina.

- Kraemer FB, Castiglioni MG, Carnevale L, Fernández PL, Morrás HJM. 2014. Porosidad estructural y textural en manejos bajo siembra directa en la región pampeana. In: Actas del XXIV Congreso Argentino de la Ciencia del Suelo, AACS; 2014 May 5-9; Bahía Blanca, Argentina.

- Kraemer FB, Castiglion MG, Morrás H. 2018. Evaluación micromorfométrica de la porosidad de un Argiudol típico con dos intensidades de uso bajo siembra directa. Cienc Suelo (Argentina) 36(1):138-157. 
- Kraemer FB, Soria MA, Castiglion MG, Duval M, Galantini J, Morrás H. 2017. Morphostructual evaluation of various soils subjected to different use intensity under no-tillage. Soil Till Res. 169:124-137.

- Kutílek M. 2004. Soil hydraulic properties as related to soil structure. Soil Till Res. 75:175-184.

- Lavelle P, Charpentier F, Cillenave C, Rossi JP, Derouard L, Pashanasi B, André J, Ponge JF, Bernier N. 2004. Effects of earthworms on soil organic matter and nutrient dynamics at a landscape scale over decades. In: Edwards CA, editor. Earthworm Ecology, 2nd edition. Boca Raton, Florida: CRC Press. p. 145-160.

- Le Bissonnais Y. 1996. Aggregate stability and assessment of soil crustability and erodibility: I. Theory and methodology. Eur J Soil Sci. 47:425-437.

- Loaiza J, Stoops G, Poch R, Casamitjana M. 2015. Manual de micromorfología de suelos y técnicas complementarias. Medellín, Colombia: Fondo Editorial Pascual Bravo. $384 \mathrm{p}$.

- Lozano LA. 2015. Desarrollo de estructura laminar del suelo en siembra directa. Factores predisponentes y efectos sobre las propiedades hidráulicas. PhD Thesis. Universidad Nacional de La Plata, Buenos Aires, Argentina.

- Maggi A, Kraemer FB, Introcaso R, Thompson D. 2016. Caracterización física y química de un Argiudol vértico de la Pampa Ondulada con erosión hídrica en el surco y entresurco. Ciencia del Suelo (Argentina) 34(1):113-126.

- Mahboubi AA, Lal R, Faussey NR. 1993. Twenty-eight years of tillage effects on two soils in Ohio. Soil Sci Soc Am J. 57:506-512.

- Mallory JJ, Mohtar RH, Heathman GC, Schulze DG, Braudeau E. 2011. Evaluating the effect of tillage on soil structural properties using the pedostructure concept. Geoderma 163:141-149.

- Moretti LM, Favret EA, Morrás HJM. 2012. Un procedimiento de medición de la porosidad en cortes delgados de suelos. Acta Microscópica 21(A):73.

- Morrás H. 2014. Porosidad y microestructura de suelos. In: Loaiza JC, Stoops G, Poch RM, Casamitjana M, editors. 2014. Manual de micromorfología de suelos y técnicas complementarias. Medellín, Colombia: Fondo Editorial Pascual Bravo.

- Morrás HJM, Bonel BA, Kraemer FB, Álvarez CA. 2012. Topsoil microstructural models in no-till Pampean Mollisols of Argentina. Morphology and development. In: Proceedings of the 14th International Working Meeting on Soil Micromorphology; 2012 Jul 8-14; Lleida, España.

- Morrás HJM, Bonel BA, Michelena R. 2004. Características microestructurales del horizonte superficial de algunos suelos pampeanos bajo siembra directa. In: Actas XIX Congreso Argentino de la Ciencia del Suelo, AACS; 2004 Jun 22-25; Paraná, Argentina.
- Morrás H, Bonel B, Moretti L, Favret E, Bressan E. 2008. Porosidad y microestructura superficial de un Argiudol típico bajo siembra directa y labranza reducida. In: Actas XXI Congreso Argentino de la Ciencia del Suelo, AACS; 2008 May 13-16; San Luis, Argentina.

- Mualem Y. 1986. Hydraulic conductivity of unsaturated soils: Prediction and formulas. In: Klute A, editor. Methods of Soil Analysis, Part 1. Physical and mineralogical methods. Madison, WI: ASA, SSSA. p. 799-823.

- Novelli LE, Caviglia OP, Melchiori RJM. 2011. Impact of soybean cropping frequency on soil carbon storage in Mollisols and Vertisols. Geoderma 167-68:254-260.

- Novelli LE, Caviglia OP, Wilson MG, Sasal MC. 2013. Land use intensity and cropping sequence effects on aggregate stability and $\mathrm{C}$ storage in a Vertisol and a Mollisol. Geoderma 195-196:260-267.

- Or D, Wraith JM. 2000. Soil water content and water potential relationships. In: Sumner ME, editor. Handbook of Soil Science. Boca Raton, Florida: CRC Press. p. 5385.

- Pachepsky YA, Timlin D, Varallyay D. 1996. Artificial neural networks to estimate soil water retention from easily measurable data. Soil Sci Soc Am J. 60:727-733.

- Pagliai M. 1987. Effects of different management practices on soil structure and surface crusting. Soil Micromorphol. 7:415-421.

- Pagliai M. 1988. Soil porosity aspects. International Agrophysics 4:215-232.

- Pagliai M, De Nobili M. 1993. Relationships between soil porosity, root development and soil enzyme activity in cultivated soils. Geoderma 56:243-256.

- Pagliai M, Kutilek M. 2008. Soil Micromorphology and Soil Hydraulics. In: Kapur S, Mermut A, Stoops G, editors. New Trends in Soil Micromorphology. Berlin: Springer Verlag. p. 5-18.

- Pagliai M, La Marca M, Lucamante G. 1983. Micromorphometric and micromorphological investigations of a clay loam soil in viticulture under zero and conventional tillage. J Soil Sci. 34:391-403.

- Pagliai M, Marca LA, Lucamante G, Genovese L. 1984. Effects of zero and conventional tillage on the length and irregularity of elongated pores in a clay loam soil under viticulture. Soil Till Res. 4:433-444.

- Pagliai M, Marsili A, Servadio P, Vignozzi N, Pellegrini S. 2003. Changes in some physical properties of a clay soil in central Italy following the passage of rubber tracked and wheeled tractors of medium power. Soil Till Res. 73:119-129.

- Pagliai M, Vignozzi N, Pellegrini S. 2004. Soil structure and the effect of management practices. Soil Till Res. 79:131-143. 
- Pastorelli R, Vignozzi N, Landi S, Piccolo R, Orsini R, Seddaiu G, Roggero P, Pagliai M. 2013. Consequences on macroporosity and bacterial diversity of adopting a notillage farming system in a clayish soil of Central Italy. Soil Biol Biochem. 66:78-93.

- Peng X, Horn RF, Hallet PD. 2015. Soil structure and its functions in ecosystems: Phase matter \& scale matter. Soil Till Res. 146:1-3

- Perfect E, Kay BD, van Loon WKP, Sheard RW, Pojasok T. 1990. Factors influencing soil structural stability within a growing season. Soil Sci Soc Am J. 54:173-179.

- Pires LF, Borges JAR, Rosa JA, Cooper M, Heck RJ, Passoni S, Roque WL. 2017. Soil structure changes induced by tillage systems. Soil Till Res. 165:66-79.

- Pires LF, Cássaro FAM, Reichardt K, Bacchi OS, Dias NMP. 2008. Micromorphological analysis to characterize structure modifications of soil samples submitted to wetting and drying cycles. Catena 72:297-304.

- Pittelkow CM, Liang X, Linquist BA, Van Groenigen KJ, Lee J, Lundy ME, Van Gestel N, Six J, Venterea RT, van Kessel C. 2015. Productivity limits and potentials of the principles of conservation agriculture. Nature 517:365368.

- Rasa K, Eickhorst T, Tippkötter R, Yli-Halla M. 2012. Structure and pore system in differently managed clayey surface soil as described by micromorphology and image analysis. Geoderma 173-174:10-18.

- Räty M, Uusi-Kämppä J, Yli-Halla M, Rasa K, Pietola P. 2010. Phosphorus and nitrogen cycles in the vegetation of differently managed buffer zones. Nutrient Cycling in Agroecosystems 86:121-132.

- Reynolds WD, Bowman BT, Drury CF, Tan CS, Lu X. 2002. Indicators of good soil physical quality: density and storage parameters. Geoderma 110:131-146.

- Reynolds WD, Drury CF, Yang XM, Tan CS. 2008. Optimal Soil Physical Quality Inferred through Structural Regression and Parameter Interactions. Geoderma 146: 466-74.

- Richards LA. 1948. Porous plate apparatus for measuring moisture retention and transmission by soil. Soil Sci. 66:105-110.

- Roduit N. 2008. JMicroVision: Image analysis toolbox for measuring and quantifying components of high-definition images. Version 1.2.7. http://www.jmicrovision.com.

- Rosa SM, Kraemer FB, Soria MA, Guerrero LD, Morrás HJM, Figuerola ELM, Erijman L. 2014. The influence of soil properties on denitrifying bacterial communities and denitrification potential in no-till production farms under contrasting management in the Argentinean Pampas. Appl Soil Ecol. 75:172-180.

- Sasal C, Andriulo A, Taboada M. 2006. Soil porosity characteristics and water movement under zero tillage in silty soils in argentinian pampas. Soil Till Res. 87:9-18.
- Sasal MC, Boizard H, Andriulo AE, Wilson MG, Léonard J. 2017b. Platy structure development under no-tillage in the northern humid Pampas of Argentina and its impact on runoff. Soil Till Res. 173:33-41.

- Sasal C, Castiglioni MG, Ferreiro JP, Wilson MG, Oszust J. 2009. Propiedades hidrológicas edáficas bajo diferentes secuencias de cultivos en siembra directa. In: Silva O, et al. Estudios en la Zona no Saturada del Suelo. Vol IX Barcelona: 2009 Nov 18-20.

- Sasal MC, Castiglioni MG, Wilson MG. 2010. Effect of crop sequences on soil properties and runoff on natural rainfall erosion plots under no tillage. Soil Till Res. 108:24-29.

- Sasal MC, Léonard J, Andriulo A, Boizard H. 2017a. A contribution to understanding the origin of platy structure in silty soils under no tillage. Soil Till Res. 173:42-48.

- Six J, Bossuyt H, Degryze S, Denef K. 2004. A history of research on the link between (micro) aggregates, soil biota, and soil organic matter dynamics. Soil Till Res. 79:7-31.

- Snedecor GW, Cochran WG. 1980. Statistical methods. 7th edition. Ames: lowa State University Press. 305 p.

- Soil Survey Staff. 1999. Soil taxonomy: A basic system of soil classification for making and interpreting soil surveys. 2nd edition. Natural Resources Conservation Service. U.S. Department of Agriculture Handbook 436.

- Stoops G. 2003. Guidelines for analysis and description of soil and regolith thin sections. Madison, WI: Soil Science Society of America. $184 \mathrm{p}$.

- Studdert GA, Echeverría HE. 2000. Crop rotations and nitrogen fertilization to manage soil organic carbon dynamics. Soil Sci Soc Am J. 64:1496-1503.

- Taboada MA, Micucci FG, Cosentino DJ, Lavado RS. 1998. Comparison of compaction induced by conventional and zero tillage in two soils of the Rolling Pampa of Argentina. Soil Till Res. 49:57-63.

- Tebrügge F, Düring RA. 1999. Reducing tillage intensity: a review of results from a long-term study in Germany. Soil Till Res. 53:15-28.

- Thomas GW, Hasxler GR, Blevins RL. 1996. The effects of organic matter and tillage on maximum compactability of soils using the proctor test. Soil Sci. 161:502-508.

- van Genuchten MT. 1980. A closed-form equation for predicting the hydraulic conductivity of unsaturated soils. Soil Sci Soc Am. J. 44:892-898.

- VandenBygaard A, Fox AC, Fallow DJ, Protz R. 2000. Estimating Earthworm-Influenced Soil Structure by Morphometric Image Analysis. Soil Sci Soc Am J. 64(3):982-988.

- VandenBygaart A, Protz R, Tomlin A, Miller J. 1999. Tillage system effects on near-surface soil morphology: observations from the lanscape to micro-scale in silt loam soils of southwestern Ontario. Soil Till Res. 51:139-149. 
- Vázquez L, Myhre DL, Gallaher RN, Hanlon EA, Portier KM. 1989. Soil compaction associated with tillage treatments for soybean. Soil Till Res. 13:35-45.

- Viglizzo EF, Frank FC, Carreno LV, Jobbágy EG, Pereyra H, Clatt J, Pincén D, Ricard MF. 2011. Ecological and environmental footprint of 50 years of agricultural expansion in Argentina. Global Change Biol. 17: 959-973.

- Wall LG. 2011. The BIOSPAS Consortium: Soil Biology and Agricultural Production. In: de Bruijn FJ, editor. Handbook of Molecular Microbial Ecology I. Hoboken, NJ: John Wiley \& Sons, Inc. p. 299-306.

- Watson KW, Luxmoore RJ. 1986. Estimating macroporosity in a forest watershed by use of a tension infiltrometer. Soil Sci Soc Am J. 50:578-582.

- Wilson M, Oszust J, Sasal C, Paz Gonzales A. 2010. Variación espacial de la resistencia mecánica a la penetración y su relación con estados estructurales del suelo bajo distintas secuencias de cultivos. In: Actas del XXII Congreso Argentino de la Ciencia del Suelo, AACS; 2010 May 31-04; Rosario, Argentina.

- Zaccagnini M, Calamari N. 2001. Labranzas conservacionistas, siembra directa y biodiversidad. In: Panigatti J, Buschiazzo D, Marelli $H$, editors. Siembra Directa II. Buenos Aires: Ediciones del INTA. p. 29-68. 